Article

\title{
Synthesis and Characterization of Positively Charged Pentacationic [60]Fullerene Monoadducts for Antimicrobial Photodynamic Inactivation
}

\author{
Sammaiah Thota ${ }^{1}$, Min Wang ${ }^{1}$, Seaho Jeon ${ }^{1}$, Satyanarayana Maragani ${ }^{1}$, \\ Michael R. Hamblin ${ }^{2,3,4, *}$ and Long Y. Chiang ${ }^{1,5, *}$
}

1 Department of Chemistry, Institute of Nanoscience and Engineering Technology, University of Massachusetts, Lowell, MA 01854, USA

2 Wellman Center for Photomedicine, Massachusetts General Hospital, Boston, MA 02114, USA

3 Department of Dermatology, Harvard Medical School, Boston, MA 02115, USA

4 Harvard-MIT Division of Health Sciences and Technology, Cambridge, MA 02139, USA

5 Department of Laboratory Medicine and Pathobiology, University of Toronto, Toronto, ON M5S 1A8, Canada

* Authors to whom correspondence should be addressed; E-Mails: Long_Chiang@uml.edu (L.Y.C.); hamblin@helix.mgh.harvard.edu (M.R.H.).

Received: 31 March 2012; in revised form: 22 April 2012 / Accepted: 28 April 2012 /

Published: 7 May 2012

\begin{abstract}
We designed and synthesized two analogous pentacationic [60]fullerenyl monoadducts, $\mathrm{C}_{60}\left(>\mathrm{ME}_{1} \mathrm{~N}_{6}{ }^{+} \mathrm{C}_{3}\right)$ (1) and $\mathrm{C}_{60}\left(>\mathrm{ME}_{3} \mathrm{~N}_{6}{ }^{+} \mathrm{C}_{3}\right)$ (2), with variation of the methoxyethyleneglycol length. Each of these derivatives bears a well-defined number of cationic charges aimed to enhance and control their ability to target pathogenic Gram-positive and Gram-negative bacterial cells for allowing photodynamic inactivation. The synthesis was achieved by the use of a common synthon of pentacationic $N, N^{\prime}, N, N, N, N$-hexapropylhexa(aminoethyl)amine arm $\left(\mathrm{C}_{3} \mathrm{~N}_{6}{ }^{+}\right)$having six attached propyl groups, instead of methyl or ethyl groups, to provide a well-balanced hydrophobicity-hydrophilicity character to pentacationic precursor intermediates and better compatibility with the highly hydrophobic $\mathrm{C}_{60}$ cage moiety. We demonstrated two plausible synthetic routes for the preparation of $\mathbf{1}$ and $\mathbf{2}$ with the product characterization via various spectroscopic methods.
\end{abstract}

Keywords: pentacationic $\mathrm{C}_{60}$ monoadducts; decacationic $\mathrm{C}_{60}$ monoadduct; $N, N^{\prime}, N, N, N, N$ hexapropyl-hexa(aminoethyl)amine; photosensitizer 


\section{Introduction}

Broad-spectrum one-photon based photodynamic therapy $(1 \gamma$-PDT)-mediated killing of pathogenic Gram-positive (e.g., Staphylococcus aureus) and Gram-negative (e.g., Escherichia coli) bacterial targets using a conventionally accessible light source is an emerging medical approach to treat infectious diseases, especially, those caused by multi-antibiotic-resistant bacteria [1-5]. The efficacy of $1 \gamma$-PDT depends on several parameters, including photophysical characteristics of the photosensitizer, the ability of the photosensitizer to target bacteria, the method of administration, and the availability of an appropriate light source. Fullerenes are highly photostable molecules suitable for single-dose multiple-treatments applications. Nearly quantitative efficiency of intersystem crossing from the excited singlet state of [60]fullerene $\left({ }^{1} \mathrm{C}_{60}{ }^{*}\right)$ to its triplet excited state $\left({ }^{3} \mathrm{C}_{60} *\right)$ readily allows intermolecular triplet energy transfer from ${ }^{3} \mathrm{C}_{60} *$ to molecular oxygen leading to the production of singlet oxygen $\left({ }^{1} \mathrm{O}_{2}\right)$ [6,7], which is highly reactive toward biological substrates producing subsequent cell damage. This photochemical mechanism serves as the basis of photodynamic cytotoxicity against pathogenic microorganisms, including multi-antibiotic-resistant bacteria. However, chemical functionalization of $\mathrm{C}_{60}$ is necessary to enhance its solubility in water. In general, attachment of multiple hydroxyl, carboxylic acid, and glycolic oxide addend groups may serve the purpose. Water-solubility of these derivatives increases as the number of hydrophilic groups increases, whether these functional groups are located in either the same addend group or different addend moieties. The latter case leads to the synthesis of fullerenyl multiadducts that may change significantly the molecular orbital configuration of the fullerene cage and, thus, its HOMO-LUMO energy gap level and effectiveness in the production of ${ }^{1} \mathrm{O}_{2}$. The $1 \gamma$-PDT efficiency can be optimized by performing only a limited number of addition reactions to the fullerenyl olefinic bonds to preserve the low HOMO-LUMO energy gap level of the cage. This restriction suggests that [60]fullerene monoadducts using hydrophilic or amphiphilic groups would be suitable candidates. However, since only one addend group is able to be attached to the cage in a monoadducts, sufficient hydrophilicity is required to allow compatibility of the resulting derivative with water.

It has been demonstrated that polycationic photosensitizers exhibited high activity as $1 \gamma$-PDT agents for targeting and photokilling against both Gram-positive and Gram-negative bacterial species [8,9]. These reported findings revealed the importance of cell surface interactions between multicationic drug molecules and anionic peptide residues in the cell wall. Specifically, several factors including differences in physiology, cell wall, and cytoplasmic membrane structures between Gram-positive and Gram-negative bacteria [10-12] affect the properties of particular functional groups to be attached on the fullerene cage to allow effective targeting selectivity, drug-delivery, and photodynamic inactivation.

Accordingly, we considered the structural modification of $\mathrm{C}_{60}$ to allow the increase of its solubility in physiologic media and its compatibility in an environment of bacterial disease in tissue. This led to our design and synthesis of [60]fullerenyl monoadducts bearing a well-defined high number of cationic charges that hitherto had remained challenging and has rarely been reported to date. In this paper, we describe a rational linkage of water-soluble quaternary alkylammonium multi-salts and ester-amide functional groups to a well-defined pentacationic arm together with an efficient synthetic method for its attachment on a $\mathrm{C}_{60}$ nanocage. The synthesis led to the preparation of new pentacationic [60]fullerene-based nano-photosensitizers 1 and 2, as shown in Schemes 1 and 2. 
Scheme 1. The first synthetic steps of $\mathrm{C}_{60}\left(>\mathrm{ME}_{1} \mathrm{~N}_{6}{ }^{+} \mathrm{C}_{3}\right) \mathbf{1}$ and $\mathrm{C}_{60}\left(>\mathrm{ME}_{3} \mathrm{~N}_{6}{ }^{+} \mathrm{C}_{3}\right) 2$.

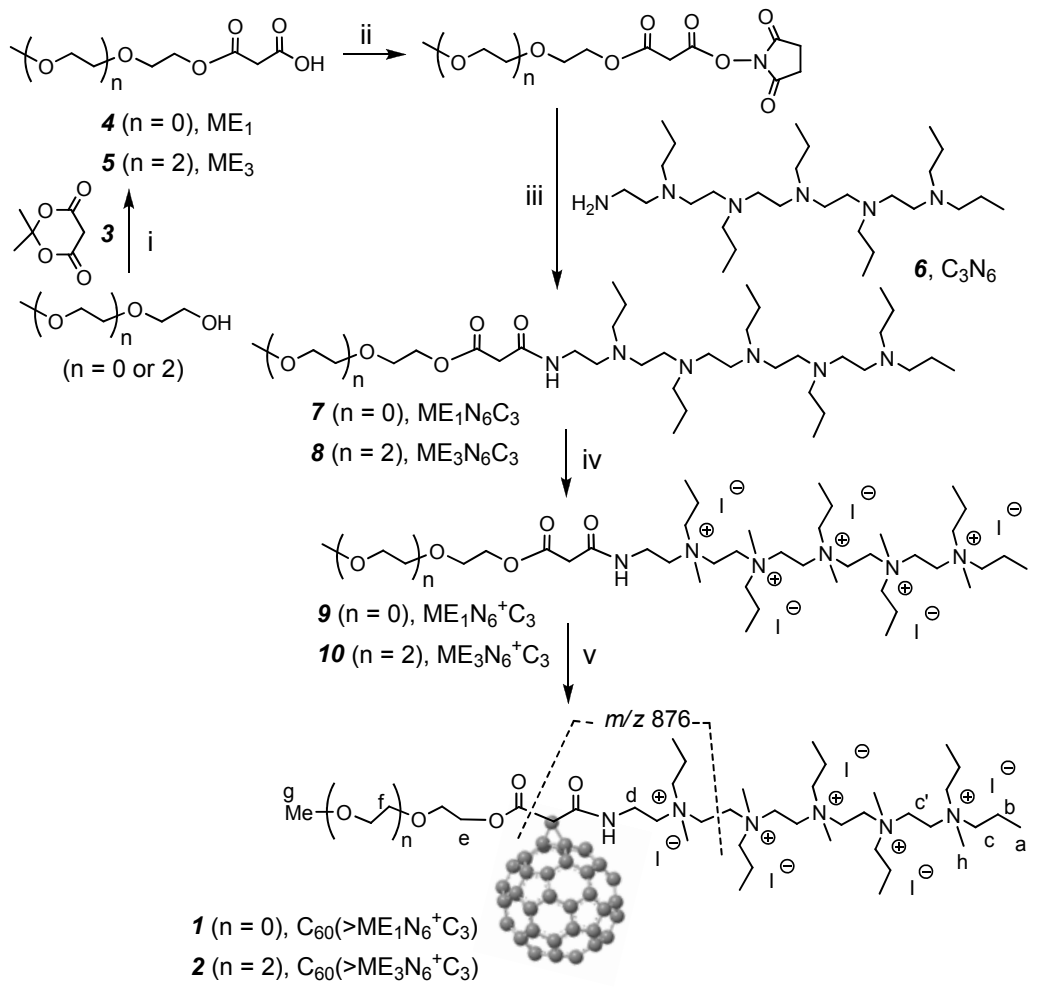

Reagents and conditions: i. Meldrum's acid, $95^{\circ} \mathrm{C}, 12 \mathrm{~h}$; ii. NHS, DCC, THF, r.t., 1.0 day; iii. THF, r.t., 12 h; iv. $\mathrm{CH}_{3}-\mathrm{I}, \mathrm{CHCl}_{3}-\mathrm{DMF}, 45^{\circ} \mathrm{C}, 3.0$ days; v. $\mathrm{C}_{60}, \mathrm{CBr}_{4}$, DBU, toluene-DMF, r.t., 10 h.

Scheme 2. The second synthetic steps of $\mathrm{C}_{60}\left(>\mathrm{ME}_{1} \mathrm{~N}_{6}{ }^{+} \mathrm{C}_{3}\right) \mathbf{1}$ and $\mathrm{C}_{60}\left(>\mathrm{ME}_{3} \mathrm{~N}_{6}{ }^{+} \mathrm{C}_{3}\right) 2$.

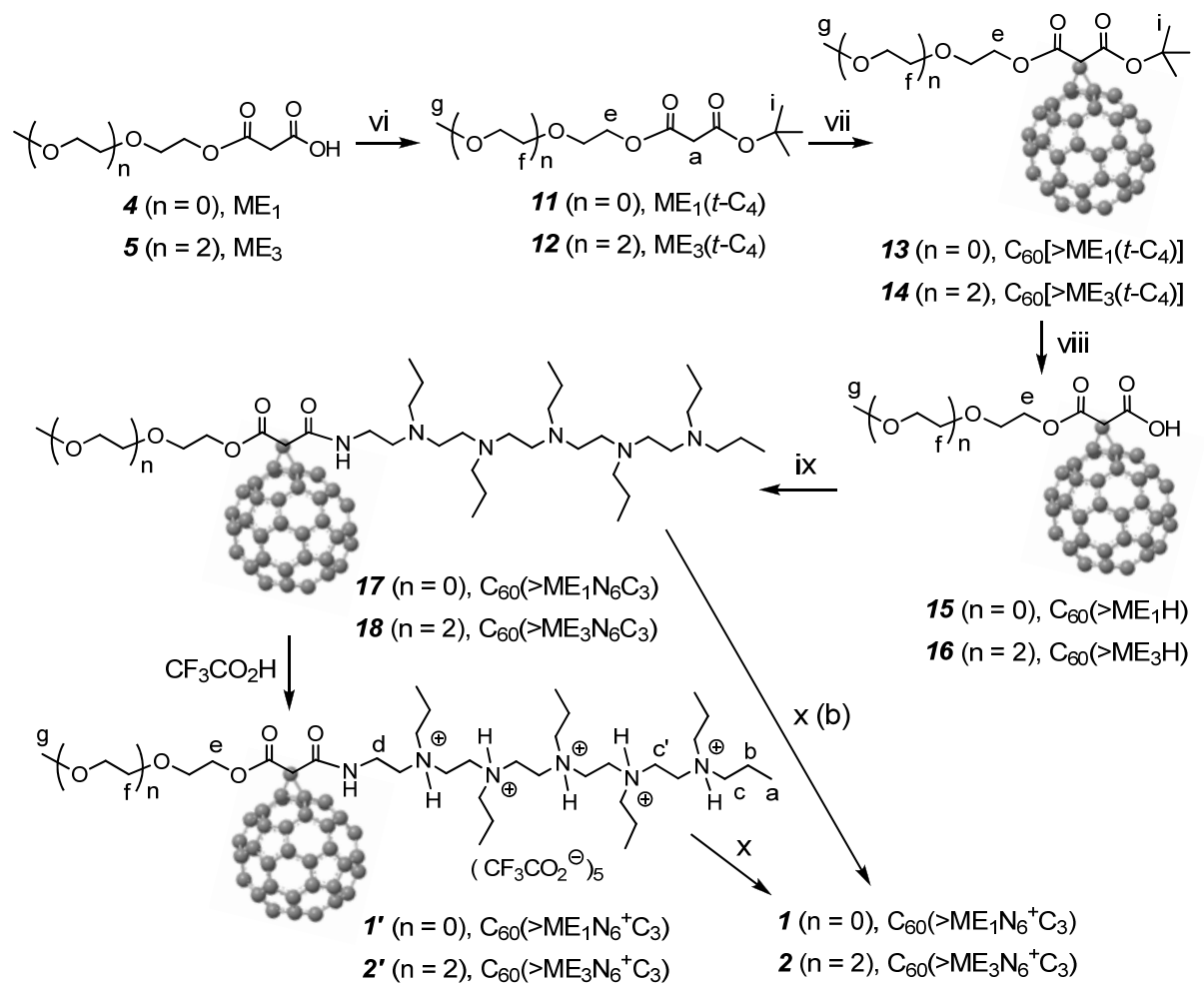

Reagents and conditions: vi. DCC, 2-methyl-2-propanol, $\mathrm{CH}_{2} \mathrm{Cl}_{2}$, r.t., 8.0 h; vii. $\mathrm{C}_{60}, \mathrm{DBU}$, toluene-ODCB, r.t., $12 \mathrm{~h}$; viii. TFA, $\mathrm{CH}_{2} \mathrm{Cl}_{2}$, r.t., $15 \mathrm{~h}$; ix. (a) $\mathrm{SOCl}_{2}$, THF, reflux, $2.0 \mathrm{~h}$; (b) $\mathrm{N}_{5} \mathrm{C}_{3}-\mathrm{NH}_{2}, 0{ }^{\circ} \mathrm{C}$-r.t., 3.0 h; x. (a) aq. $\mathrm{K}_{2} \mathrm{CO}_{3}\left(10 \%\right.$ ); (b) $\mathrm{CH}_{3}-\mathrm{I}, \mathrm{CHCl}_{3}-\mathrm{DMF}, 45^{\circ} \mathrm{C}, 3.0$ days. 
In these structures, arm moieties each bearing a high number of cationic charges and an amide moiety are capable of inducing the H-bonding in the vicinity of the fullerene cage.

\section{Results and Discussion}

Enhancement of the hydrophilicity of fullerene derivatives can be achieved by incorporation of the oligo(ethylene glycol) unit [13-15], an aminoacid moiety [16], or ionic functional groups [17-19] as addend attachments of $\mathrm{C}_{60}$ cage. The resulting amphiphilic derivatives have been reported to undergo different forms of solid aggregation in aqueous solution if the hydrophilic moiety of the addend is insufficiently large to overcome the high hydrophobicity of the fullerene cage. To circumvent this solid aggregation problem, we undertook the effort to synthesize a well-defined water-soluble pentacationic $N, N^{\prime}, N, N, N, N$-hexapropyl-hexa(aminoethyl)amine arm moiety $\mathrm{C}_{3} \mathrm{~N}_{6}{ }^{+}$, as a charged $\mathrm{C}_{3} \mathrm{~N}_{6}$ (6), with the number of charge being fixed at five per arm and used as the common synthon in the preparation of [60]fullerene monoadducts, as shown in Scheme 1. One example was given by the combination of a water-compatible ethylene glycol unit with a $\mathrm{C}_{3} \mathrm{~N}_{6}{ }^{+}$arm to a single addend, such as the arm precursors $\mathrm{ME}_{1} \mathrm{~N}_{6}{ }^{+} \mathrm{C}_{3}(\mathbf{9})$ and $\mathrm{ME}_{3} \mathrm{~N}_{6}{ }^{+} \mathrm{C}_{3}(\mathbf{1 0})$, to enhance the water-solubility. Synthesis of 9 and 10 began with the reaction of either 2-methoxyethanol or triethylene glycol monomethyl ether with 2,2-dimethyl-1,3-dioxane-4,6-dione (3, Meldrum's acid) at 90-95 ${ }^{\circ} \mathrm{C}$ for a period of $12 \mathrm{~h}$ to afford malonic acid methoxyethyleneglycol ester, $\mathrm{ME}_{1}$ (4), or malonic acid methoxytriethyleneglycol ester, $\mathrm{ME}_{3}$ (5), in 95 or $90 \%$ yield, respectively. Amidation reaction of $\mathbf{4}$ and $\mathbf{5}$ was carried out by the treatment with $N$-hydroxysuccinamide and $N, N^{\prime}$-dicyclohexyl carbodiimide (DCC) in anyhydrous THF at ambient temperature over a period of $12 \mathrm{~h}$, followed by the removal of insoluble byproduct of $N, N^{\prime}$-dicyclohexyl urea and the further treatment with $N, N^{\prime}, N, N, N, N$-hexapropyl-hexa(aminoethyl)amine, $\mathrm{C}_{3} \mathrm{~N}_{6}(6)$, for an additional period of $12 \mathrm{~h}$. These reactions resulted in the corresponding products of methoxyethyleneglycol-[ $N, N^{\prime}, N, N, N, N$-hexapropyl-hexa(aminoethyl)-amino]malonamide ester, $\mathrm{ME}_{1} \mathrm{~N}_{6} \mathrm{C}_{3}$ (7), and methoxy-tri(ethyleneglycol)-[ $\left[N, N^{\prime}, N, N, N, N\right.$-hexapropyl-hexa(aminoethyl)amino]malonamide ester, $\mathrm{ME}_{3} \mathrm{~N}_{6} \mathrm{C}_{3}(\mathbf{8})$, in 82 and $80 \%$ yield, respectively. Quaternization reaction of mono- and tri(ethoxylated) hexaaminomalonamide precursors 7 and $\mathbf{8}$ using methyl iodide as the methylation agent at $45-50{ }^{\circ} \mathrm{C}$ for a period of 3.0 days afforded the corresponding methoxyethyleneglycol$\left[N, N^{\prime}, N, N, N, N\right.$-hexapropyl-hexa(aminoethyl)amino]malonamide ester methyl quaternary ammonium salt, $\mathrm{ME}_{1} \mathrm{~N}_{6}{ }^{+} \mathrm{C}_{3}$ (9), and its tri(ethyleneglycolated) analogue $\mathrm{ME}_{3} \mathrm{~N}_{6}{ }^{+} \mathrm{C}_{3}$ (10) in 94 and $92 \%$ yield, respectively. Attachment of a $\mathrm{C}_{60}$ cage on the quaternary ammonium salts of malonamide was accomplished by the treatment of $\mathbf{9}$ and $\mathbf{1 0}$ in DMF with predissolved $\mathrm{C}_{60}$ in toluene in the presence of 1.8-diazabicyclo[5.4.0]-undec-7-ene (DBU) at ambient temperature for a period of $8.0 \mathrm{~h}$. In this reaction, carbon tetrabromide was applied as the bromination agent for the replacement of malonyl $\alpha$-proton in situ. To minimize the possible formation of partial fullerenyl byproducts containing multiaddends, an excess amount (2.5 equiv.) of $\mathrm{C}_{60}$ was applied. At the end of fullerenation, an excessive amount of $\mathrm{C}_{60}$ molecules was recovered and removed by repeatedly washing the crude products with toluene until the observation of a clear toluene solution in washings. The reaction procedure led to the isolation of methoxyethyleneglycol-(20-oxo-4,7,10,13,16-pentapropyl4,7,10,13,16,19-hexaaza-nonadecan-19-yl)[60]fullerenyl malonate quaternary methyl ammonium salt, 
$\mathrm{C}_{60}\left(>\mathrm{ME}_{1} \mathrm{~N}_{6}{ }^{+} \mathrm{C}_{3}\right)$ (1), and its tri(ethyleneglycolated) analogue $\mathrm{C}_{60}\left(>\mathrm{ME}_{3} \mathrm{~N}_{6}{ }^{+} \mathrm{C}_{3}\right)$ (2) in 55 and $50 \%$ yield, respectively.

Alternatively, as shown in Scheme 2, (ethyleneglycolated)malonic acids 4 and 5 were converted to their corresponding tert-butyl(2-methoxyethyl)malonate ester, $\mathrm{ME}_{1}\left(t-\mathrm{C}_{4}\right)$ (11), and its tri(ethyleneglycolated) analogue $\mathrm{ME}_{3}\left(t-\mathrm{C}_{4}\right)(\mathbf{1 2})$ in 74 and $77 \%$ yield, respectively, by an esterification reaction with $t$-butyl alcohol in anyhydrous dichloromethane (DCM) in the presence of $N, N^{\prime}$-dicyclohexylcarbodiimide (DCC) at ambient temperature for a period of $8.0 \mathrm{~h}$. Subsequent fullerenyl cyclopropanation reaction of $\mathbf{1 1}$ and $\mathbf{1 2}$ was carried out by treatment with [60]fullerene solution in a mixture of toluene and 1,2-dichlorobenzene in the presence of carbon tetrabromide and 1.8-diazabicyclo[5.4.0]-undec-7-ene (DBU) over a period of $12 \mathrm{~h}$ at room temperature. The products tert-butyl(2-methoxyethyl)[60]fullerenyl malonate, $\mathrm{C}_{60}\left[>\mathrm{ME}_{1}\left(t-\mathrm{C}_{4}\right)\right](\mathbf{1 3})$, and tert-butyl(methoxytriethyleneglycol)[60]fullerenyl malonate, $\mathrm{C}_{60}\left[>\mathrm{ME}_{3}\left(t-\mathrm{C}_{4}\right)\right]$ (14), were purified by column chromatography $\left[\mathrm{SiO}_{2}\right.$, toluene-ethyl acetate (20:1) as eluent] as brown solids in 78 and $75 \%$ yield, respectively. Direct transamidation reaction of 13 and 14 with $\mathrm{C}_{3} \mathrm{~N}_{6}$ was not successful owing to the complicated side-reaction arising from the attack of $\mathrm{C}_{3} \mathrm{~N}_{6}$ on $\mathrm{C}_{60}$ itself at elevated temperatures which is required for the effective transamidation. Therefore, we carried out the transformation of 13 and 14 to the corresponding methoxyethyleneglycol-(20-oxo-4,7,10,13,16-pentapropyl-4,7,10,13,16,19hexaaza-nonadecan-19-yl)[60]fullerenyl malonate 17, $\mathrm{C}_{60}\left(>\mathrm{ME}_{1} \mathrm{~N}_{6} \mathrm{C}_{3}\right)$, and its methoxytriethyleneglycol ester analogous 18, $\mathrm{C}_{60}\left(>\mathrm{ME}_{3} \mathrm{~N}_{6} \mathrm{C}_{3}\right)$, respectively, by the acid hydrolysis of $\mathbf{1 3}$ and $\mathbf{1 4}$ first to 2-[60]fullerenyl-3-(2-methoxyethoxy)-3-oxopropanoic acid 15, $\mathrm{C}_{60}\left(>\mathrm{ME}_{1} \mathrm{H}\right)$, and its methoxytriethyleneglycol ester analogous 16, $\mathrm{C}_{60}\left(>\mathrm{ME}_{3} \mathrm{H}\right)$, respectively. The latter products were obtained as brown solids in yields of $89 \%$ and $87 \%$, respectively. Conversion of $\mathbf{1 5}$ and $\mathbf{1 6}$ to their acid chloride intermediates was carried out by the reaction with thionyl chloride in THF. To minimize the amination of $\mathrm{C}_{3} \mathrm{~N}_{6}$ on $\mathrm{C}_{60}$, subsequent reaction with the acid chloride intermediate was performed at $0{ }^{\circ} \mathrm{C}$ to room temperature over a period of $3.0 \mathrm{~h}$. A relatively pure $\mathrm{C}_{60}\left(>\mathrm{ME}_{1} \mathrm{~N}_{6} \mathrm{C}_{3}\right) 17$ was obtained in $47 \%$ yield. It was accompanied with a small quantity of byproduct as a decarboxylated fullerene malonatemonoadduct that is removable. The stability of $\mathbf{1 7}$ and $\mathbf{1 8}$ in either solution or solid phase was found to be low owing to possible intermolecular complex formation between the hexaamine moiety and $\mathrm{C}_{60}$ cage giving insoluble aggregate solids. Therefore, compound $\mathbf{1 7}$ and $\mathbf{1 8}$ was quaternized to the protonated ammonium-trifluoroacetate salt $\mathrm{C}_{60}\left(>\mathrm{ME}_{1} \mathrm{~N}_{6}{ }^{+} \mathrm{C}_{3}\right) \quad\left(\mathbf{1}^{\prime}\right)$ and $\mathrm{C}_{60}\left(>\mathrm{ME}_{3} \mathrm{~N}_{6}{ }^{+} \mathrm{C}_{3}\right) \quad\left(\mathbf{2}^{\prime}\right)$, respectively, with trifluoroacetic acid in a short period of time immediately after the workup procedure and purification. Final synthesis of the products pentacationic methoxyethyleneglycol-(20-oxo4,7,10,13,16-pentapropyl-4,7,10,13,16,19-hexaaza-nonadecan-19-yl)[60]fullerenyl malonate quaternary methyl ammonium salt $\mathrm{C}_{60}\left(>\mathrm{ME}_{1} \mathrm{~N}_{6}{ }^{+} \mathrm{C}_{3}\right)$ (1), and its analogous methoxy-triethyleneglycol ester $\mathrm{C}_{60}\left(>\mathrm{ME}_{3} \mathrm{~N}_{6}{ }^{+} \mathrm{C}_{3}\right)(\mathbf{2})$, was carried out by the neutralization of $\mathbf{1}^{\prime}$ and $\mathbf{2}^{\prime}$ first with aqueous potassium carbonate in $\mathrm{CHCl}_{3}$ as a biphase solution. Resulting [60]fullerenyl malonates $\mathbf{1 7}$ and $\mathbf{1 8}$, respectively, were then transferred to a solvent mixture of anhydrous $\mathrm{CHCl}_{3}$ and $\mathrm{DMF}(2: 1)$ for methyl quaternization with an excess amount of iodomethane added portionwise over a period of 3.0 days at $45{ }^{\circ} \mathrm{C}$ to afford 1 and 2. Successful amidation conversion from malonic acid 5 to $\mathrm{ME}_{3} \mathrm{~N}_{6} \mathrm{C}_{3}$ was verified by the FT-IR spectrum of 8 (Figure 1a) showing two clear and strong vibrational carbonyl absorption bands centered at 1667 and $1736 \mathrm{~cm}^{-1}$ corresponding to malonylamide carbonyl [ $-\mathrm{NH}-\mathrm{C}(=\mathrm{O})-$ ] and ester carbonyl $(-\mathrm{C}=\mathrm{O})$ moieties, respectively. In the same spectrum, IR peaks located at 2952, 2928, 2862, and $2805 \mathrm{~cm}^{-1}$ 
were assigned to the stretching absorption bands of aliphatic $-\mathrm{C}-\mathrm{H}$. Anti-symmetric deformations of $-\mathrm{CH}_{3}$ groups and scissor vibrations of $-\mathrm{CH}_{2}$ groups appeared as medium intensity bands centered around $1456 \mathrm{~cm}^{-1}$, while symmetric deformations of $\mathrm{CH}_{3}$ groups exhibited the absorption around $1379 \mathrm{~cm}^{-1}$ that overlaps with the $-\mathrm{N}-\mathrm{C}-$ stretching vibration of amide $[-\mathrm{N}-(\mathrm{C}=\mathrm{O})-]$ bands at $1400 \mathrm{~cm}^{-1}$. A strong broad band centered at $1104 \mathrm{~cm}^{-1}$ was assigned to the stretching vibrations of $-\mathrm{C}-\mathrm{O}-\mathrm{C}-$ and $-\mathrm{C}-\mathrm{N}-$ moieties. Methyl quaternization of $\mathbf{8}$, having tertiary penta(ethylamino) arms, to $\mathrm{ME}_{3} \mathrm{~N}_{6}{ }^{+} \mathrm{C}_{3} \mathbf{1 0}$ with iodide salts showed retention of some of IR absorption bands (Figure 1b), except the shift of $-\mathrm{NH}-\mathrm{C}(=\mathrm{O})$ - band to $1669 \mathrm{~cm}^{-1}$ and a new broad band at $947 \mathrm{~cm}^{-1}$, corresponding to the absorption of a number of quaternary $-\mathrm{C}-\mathrm{N}^{+}$- bonds. Formation of $\mathrm{ME}_{3} \mathrm{~N}_{6}{ }^{+} \mathrm{C}_{3}$-attached $\mathrm{C}_{60}$ monoadduct was verified by the observation of a sharp characteristic fullerene half-cage absorption band of $\mathrm{C}_{60}\left(>\mathrm{ME}_{3} \mathrm{~N}_{6}{ }^{+} \mathrm{C}_{3}\right) 2$ at $524 \mathrm{~cm}^{-1}$ in the spectrum of Figure 1c. These results provided a good agreement of the product structure of 2. Similar infrared absorption bands of $\mathrm{C}_{60}\left(>\mathrm{ME}_{1} \mathrm{~N}_{6}{ }^{+} \mathrm{C}_{3}\right) \mathbf{1}$ were observed, except a relatively smaller $-\mathrm{C}-\mathrm{O}-\mathrm{C}-$ band than that of 2 centered at $1000-1200 \mathrm{~cm}^{-1}$.

Figure 1. FT-IR spectra of (a) $\mathrm{ME}_{3} \mathrm{~N}_{6} \mathrm{C}_{3} \mathbf{8}$, (b) $\mathrm{ME}_{3} \mathrm{~N}_{6}{ }^{+} \mathrm{C}_{3} \mathbf{1 0}$, and (c) $\mathrm{C}_{60}\left(>\mathrm{ME}_{3} \mathrm{~N}_{6}^{+} \mathrm{C}_{3}\right) 2$.

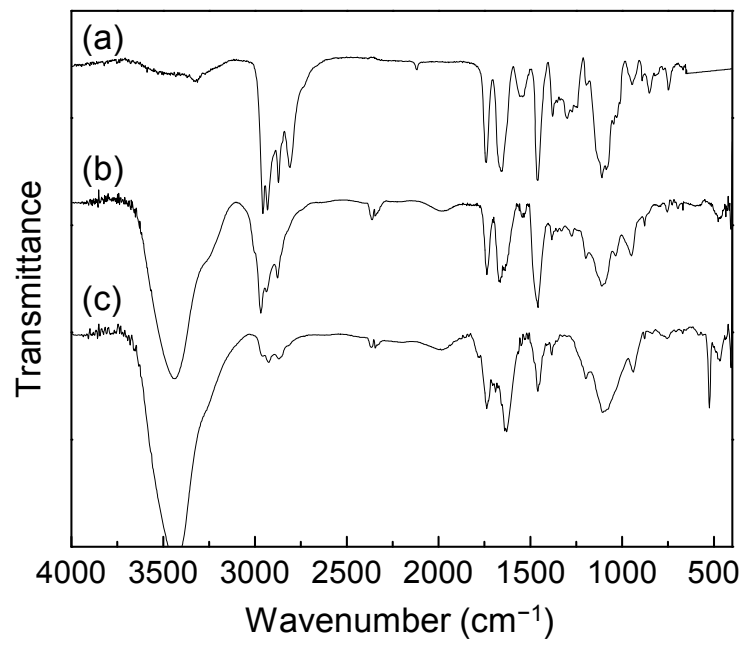

Mass spectroscopic data collection of both $\mathbf{1}$ and $\mathbf{2}$ was proven to be difficult due to their polycationic nature and facile fragmentations occurring at the conjunction of the $\mathrm{C}_{60}$ cage and the pentacationic malonate arm, giving mainly the highly detectable $\mathrm{C}_{60}$ ion mass fragment at $\mathrm{m} / \mathrm{z} 721$, as displayed in MALDI-TOF mass spectra using sinapic acid as the matrix. All fragmented high mass ions were very weak in intensity including peaks at $m / z 1930\left(\mathrm{M}^{+}-\mathrm{I}^{-}\right)$(supporting information) and $2019\left(\mathrm{MH}^{+}-\mathrm{I}^{-}\right)$as the molecular ion of $\mathbf{1}$ and $\mathbf{2}$, respectively. The most pronounced mass fragmentation ions at $m / z 874$ and 876 in both spectra of $\mathbf{1}$ and $\mathbf{2}$ were assigned to the substructure of $\mathrm{C}_{60}\left[>\mathrm{H}(\mathrm{C}=\mathrm{O}) \mathrm{NHCH}_{2} \mathrm{CH}_{2} \mathrm{~N}^{+}-\mathrm{PrMe}_{2}\right]$, indicating a main malonylamide moiety being attached on a $\mathrm{C}_{60}$ cage, consistent with the [60]fullerenyl monoadduct structure.

In the case ${ }^{1} \mathrm{H}-\mathrm{NMR}$ spectroscopic analyses, we first well-characterized the arm structures $\mathrm{ME}_{1}\left(t-\mathrm{C}_{4}\right)$ (11, Figure 2a) and $\mathrm{ME}_{3}\left(t-\mathrm{C}_{4}\right)(\mathbf{1 2})$ by identification of all protons $\left(\mathrm{H}_{\alpha}, \mathrm{H}_{\mathrm{e}}, \mathrm{H}_{\mathrm{f}}, \mathrm{H}_{\mathrm{g}}\right.$, and $\mathrm{H}_{\mathrm{i}}$ indicated in Scheme 2) with their assignments to peaks shown in the spectra. Attachment of $\mathbf{1 1}$ on $\mathrm{C}_{60}$ leading to a monoadduct $\mathrm{C}_{60}\left[>\mathrm{ME}_{1}\left(t-\mathrm{C}_{4}\right)\right](\mathbf{1 3})$ was evident by the disappearance of a $\mathrm{H}_{\alpha}$ proton peak with the chemical shift at $\delta 3.33$. It was also accompanied with up-fielded shifts of two proton peaks to $\delta 3.06$ and 3.26, corresponding to the chemical shift of terminal methoxy protons $\mathrm{H}_{\mathrm{g}}$ and ethylene oxide 
protons $\mathrm{H}_{\mathrm{f}}$, in toluene- $d_{8}$ from $\delta 3.34$ and 3.56 of 11 in $\mathrm{CDCl}_{3}$, respectively, reflecting partly the solvent effect. Hydrolysis of 13 to $\mathrm{C}_{60}\left(>\mathrm{ME}_{1} \mathrm{H}\right)(\mathbf{1 5})$ was also apparent by the loss of $t$-butyl protons at $\delta$ 1.55, as shown in Figures $2 \mathrm{~b}$ and $2 \mathrm{c}$, accompanied with down-fielded shifts of proton peaks $\left(\mathrm{H}_{\mathrm{g}}, \mathrm{H}_{\mathrm{f}}\right.$, and $\mathrm{H}_{\mathrm{e}}$ ) to $\delta 3.34,3.71$, and 4.59 , respectively, in THF- $d_{8}$ showing a larger solvent effect. Monoadduct structures of $\mathbf{1 3}$ and $\mathbf{1 4}$ were also confirmed by the detection of well-defined characteristic fullerenyl $\mathrm{sp}^{2}$ carbon peaks in their ${ }^{13} \mathrm{C}$-NMR spectra (Figure $3 \mathrm{~b}$ ) showing a group of 26 and 27 peaks, respectively, each accounted for two carbons and a group of 6 single carbon peaks for $\mathbf{1 3}$ (two of these single carbon peaks may be derived from the slightly unsymmetrical environment around the malonate moiety) and 4 single carbon peaks for 14 in the region of $\delta 135-150$, consistent with a $C_{\mathrm{v}}$ molecular symmetry for both 13 and 14. It also displayed two clear carbonyl carbon peaks at $\delta 163.45(\mathrm{O}=\mathbf{C}$-O-tert-butyl $)$ and $161.86(\mathrm{O}=\mathbf{C}-\mathrm{O}-)$ in toluene- $d_{8}$, for $\mathbf{1 3}$ and the corresponding peaks at $\delta 163.95$ and 162.16 in $\mathrm{CDCl}_{3}$ for 14. Evidence of the acid formation in the structure of $\mathbf{1 5}$ and $\mathrm{C}_{60}\left(>\mathrm{ME}_{3} \mathrm{H}\right)(\mathbf{1 6})$ was given by the solubility change and up-fielded shifts of the carbonyl chemical-shift to $\delta 161.13(\mathrm{O}=\mathbf{C}-\mathrm{OH})$ and $161.62(\mathrm{O}=\mathbf{C}-\mathrm{O}-)$ in THF- $d_{8}-\mathrm{CS}_{2}(2: 1)$ for 15 (Figure $3 \mathrm{c}$ ), partly due to the solvent effect. More clear changes of carbonyl carbon peak positions were observed for the case of $\mathbf{1 6}$ showing down-fielded shifts to $\delta 163.79(\mathrm{O}=\mathbf{C}-\mathrm{OH})$ and $164.12(\mathrm{O}=\mathbf{C}-\mathrm{O}-)$ (Figure $3 \mathrm{~d})$ from those of $\mathbf{1 4}$ in the same solvent, consistent with the corresponding structural modification.

Figure 2. ${ }^{1} \mathrm{H}$ NMR spectra of (a) 11 in $\mathrm{CDCl}_{3}$, (b) 13 in toluene- $d_{8}$, (c) 15 in THF- $d_{8}$, (d) 1 ' in $\mathrm{CDCl}_{3}-$ toluene- $d_{8}$, and (e) 1 in DMSO- $d_{6}-$ toluene- $d_{8}$.

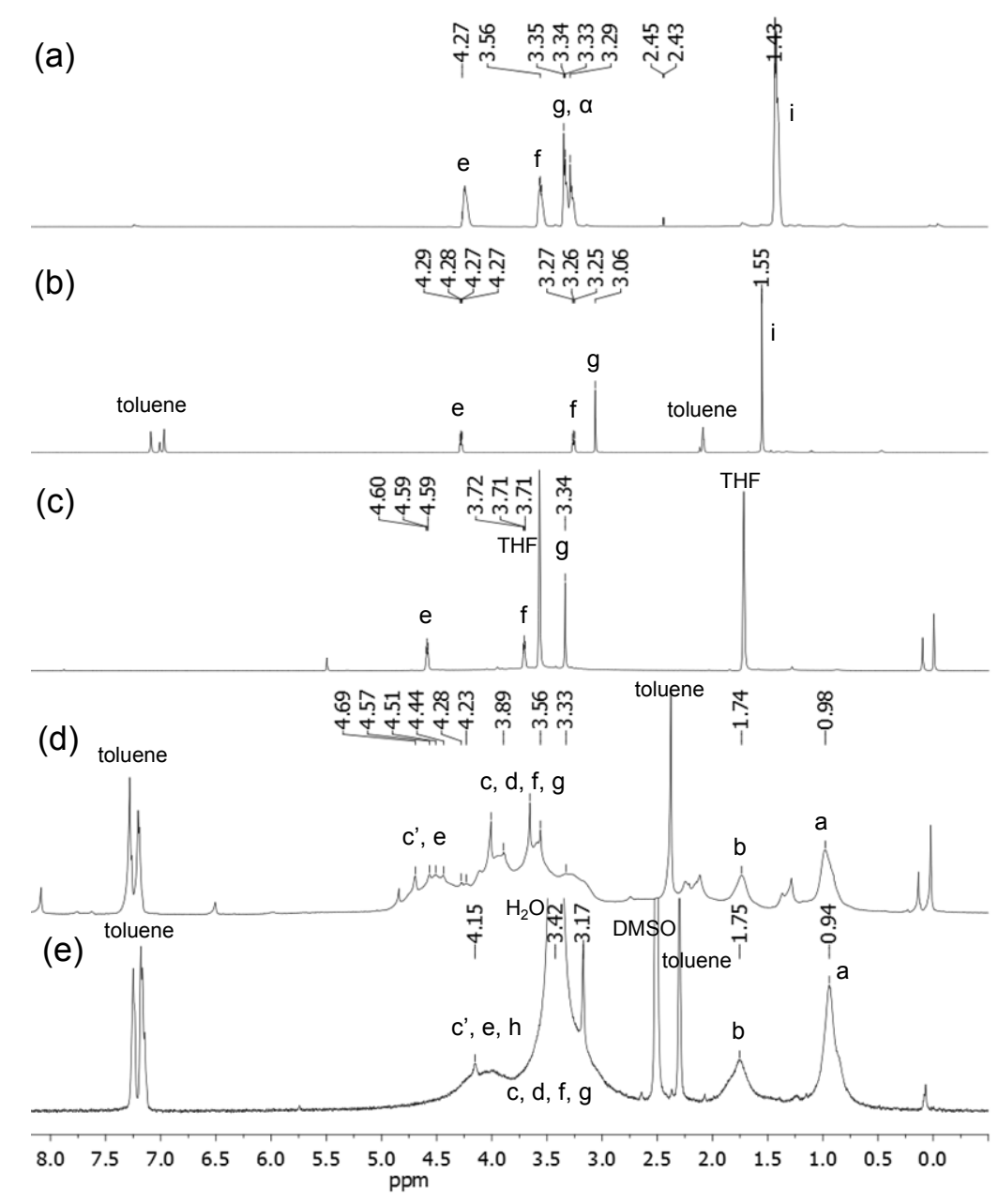


Figure 3. ${ }^{13} \mathrm{C}-\mathrm{NMR}$ spectra of (a) 13 in toluene- $d_{8}$; (b) 14 in $\mathrm{CDCl}_{3}$; (c) 15 in THF- $d_{8}-\mathrm{CS}_{2}$; (d) $\mathbf{1 6}$ in $\mathrm{CDCl}_{3}$; and (e) $\mathbf{1}^{\prime}$ in $\mathrm{CDCl}_{3}$.
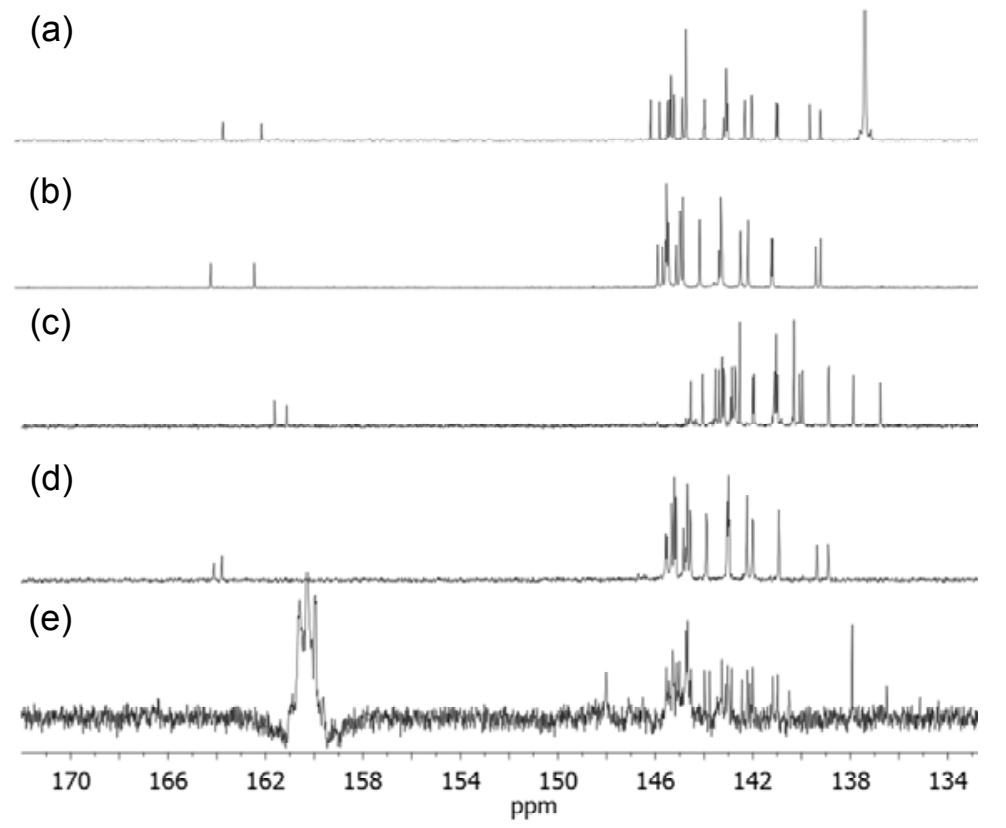

In addition, the spectra of both compounds $\mathbf{1 5}$ and $\mathbf{1 6}$ displayed a group of 27 peaks each accounted for two $\mathrm{sp}^{2}$ fullerenyl carbons and four single $\mathrm{sp}^{2}$ carbon peaks in the region of $\delta 135-145$ provided the further confirmation of a $C_{\mathrm{v}}$ molecular symmetry of $\mathrm{C}_{60}\left(>\mathrm{ME}_{1} \mathrm{H}\right)$ and $\mathrm{C}_{60}\left(>\mathrm{ME} \mathrm{E}_{3} \mathrm{H}\right)$, respectively, as monoadducts without change during the chemical reaction.

Attachment of hexa(aminoethyl)amine $\mathrm{C}_{3} \mathrm{~N}_{6}{ }^{+}$arm to the malonic acid moiety of $\mathrm{C}_{60}\left(>\mathrm{ME}_{1} \mathrm{H}\right)$ leading to the structure of $\mathrm{C}_{60}\left(>\mathrm{ME}_{1} \mathrm{~N}_{6}{ }^{+} \mathrm{C}_{3}\right) \mathbf{1}^{\prime}$ and subsequently $\mathbf{1}$ was confirmed by the analyses of both infrared and ${ }^{1} \mathrm{H}-\mathrm{NMR}$ spectra. The latter of $\mathbf{1}^{\prime}$ showed proton peaks corresponding to the $\mathrm{C}_{3} \mathrm{~N}_{6}{ }^{+}$ arm moiety with overlap of a number of terminal ammonium-propyl $\alpha$-protons $\left(\mathrm{H}_{\mathrm{c}}\right)$, $\alpha$-protons to amide group $\left(\mathrm{H}_{\mathrm{d}}\right)$, glycol ether protons $\left(\mathrm{H}_{\mathrm{f}}\right)$, and terminal methoxy protons $\left(\mathrm{H}_{\mathrm{g}}\right)$ giving broad multiplet peaks in the region of $\delta 3.0-4.25$ in $\mathrm{CDCl}_{3}$-toluene- $d_{8}$ (Figure 2d). The second broad multiplet peaks in the region of $\delta 4.25-4.75$ were assigned to ammonium-ethyl protons $\left(\mathrm{H}_{\mathrm{c}^{\prime}}\right)$ and $\alpha$-protons to the ester group $\left(\mathrm{H}_{\mathrm{e}}\right)$. In the case of $\mathbf{1}$, chemical shifts of similar groups of protons $\left(\mathrm{H}_{\mathrm{c}}, \mathrm{H}_{\mathrm{d}}, \mathrm{H}_{\mathrm{f}}\right.$, and $\left.\mathrm{H}_{\mathrm{g}}\right)$ and $\left(\mathrm{H}_{\mathrm{c}^{\prime}}\right.$, $\mathrm{H}_{\mathrm{e}}$, and ammonium-methyl protons $\mathrm{H}_{\mathrm{h}}$ ) were assigned to those of broad multiplet peaks at $\delta 3.0-3.75$ and 3.75-4.5, respectively, in DMSO- $d_{6}$-toluene- $d_{8}$ (2:1), as shown in Figure 2(e). Interestingly, ${ }^{13} \mathrm{C}$-NMR spectrum of $\mathrm{C}_{60}\left(>\mathrm{ME}_{1} \mathrm{~N}_{6}{ }^{+} \mathrm{C}_{3}\right) \mathbf{1}^{\prime}$ (Figure $3 \mathrm{e}$ ) showed a group of 27 peaks each accounted for two $\mathrm{sp}^{2}$ fullerenyl carbons and four single $\mathrm{sp}^{2}$ carbon peaks (two of them having an identical chemical shift) in the region of $\delta 135-150$ that provided a clear confirmation of a $C_{\mathrm{v}}$ molecular symmetry of $\mathrm{C}_{60}\left(>\mathrm{ME}_{1} \mathrm{~N}_{6}{ }^{+} \mathrm{C}_{3}\right)$ monoadduct.

\section{Experimental}

\subsection{Materials}

The reagents 2-methoxyethanol, triethylene glycol monomethyl ether, 2,2-dimethyl-1,3-dioxane4,6-dione (Meldrum's acid), $N$-hydroxysuccinamide (NHS), $N, N^{\prime}$-dicyclohexyl carbodiimide (DCC), 
iodomethane, carbon tetrabromide $\left(\mathrm{CBr}_{4}\right)$, 1,8-diazabicyclo[5,4,0]-undec-7-ene (DBU), 2-methyl-2propanol, trifluoroacetic acid (TFA), thionyl chloride $\left(\mathrm{SOCl}_{2}\right), \mathrm{K}_{2} \mathrm{CO}_{3}, \gamma$-butyrolactone (GBL), $\mathrm{BF}_{3} \cdot \mathrm{Et}_{2} \mathrm{O}$, triethylamine, and pyridine were purchased from Aldrich Chemicals and used without further purification. Malonyl chloride was purchased from TCI America. A $\mathrm{C}_{60}$ sample with a purity of 99.0\% was used. Sodium sulfate was employed as a drying agent. Solvents were routinely distilled before use.

\subsection{Spectroscopic Measurements}

Infrared spectra were recorded as $\mathrm{KBr}$ pellets on a Thermo Nicolet Avatar 370 FT-IR spectrometer. ${ }^{1} \mathrm{H}-\mathrm{NMR}$ and ${ }^{13} \mathrm{C}-\mathrm{NMR}$ spectra were recorded on a Bruker Avance Spectrospin-500 spectrometer. UV-Vis spectra were recorded on a Perkin Elmer Lambda 750 UV-Vis-NIR Spectrometer. MALDI-mass spectra were recorded on a WATERS Micromass MALDI-TOF mass spectrometer. Elemental analysis was taken by Galbraith Laboratories, Inc. (Knoxville, TN, USA).

\subsection{Synthetic Procedures}

\subsubsection{Synthesis of Malonic Acid Methoxyethyleneglycol Ester, $\mathrm{ME}_{1}$ (4)}

A mixture of 2-methoxyethanol (1.0 g, $13.1 \mathrm{mmol})$ and 2,2-dimethyl-1,3-dioxane-4,6-dione (3, Meldrum's acid, $1.9 \mathrm{~g}, 13.2 \mathrm{mmol}$ ) was stirred under an Ar atmosphere over a period of $12 \mathrm{~h}$ at $95{ }^{\circ} \mathrm{C}$. The reaction mixture was cooled to room temperature, treated with aqueous sodium carbonate solution (5\%), and washed with diethyl ether. The resulting aqueous layer was subsequently treated with dil. $\mathrm{HCl}(2.0 \mathrm{~N})$ and extracted with ethyl acetate $(50 \mathrm{~mL})$. The ethyl acetate solution was dried over $\mathrm{Na}_{2} \mathrm{SO}_{4}$ and concentrated on rotary evaporator to give the product $\mathrm{ME}_{1}$ (4) in $95 \%$ yield $(2.0 \mathrm{~g})$. Spectroscopic data: FT-IR (KBr) $v_{\max } 3060$ (w), 2880 (w), 2814 (w), 1727 (vs), 1458 (w), 1399 (m), 1318 (s), 1249 (s), 1134 (s), 1100 (s), 1039 (m), 952 (w), 848 (s), and 755 (m) cm ${ }^{-1}$; ${ }^{1}$ H-NMR (500 MHz, $\left.\mathrm{CDCl}_{3}, \mathrm{ppm}\right) \delta 10.60(\mathrm{~s}, \mathrm{br}, 1 \mathrm{H}), 4.31(\mathrm{t}, J=4.63 \mathrm{~Hz}, 2 \mathrm{H}), 3.62(\mathrm{t}, J=4.63 \mathrm{~Hz}, 2 \mathrm{H}), 3.45(\mathrm{~s}, 2 \mathrm{H})$, and $3.38(\mathrm{~s}, 3 \mathrm{H})$.

\subsubsection{Synthesis of Malonic Acid Methoxytriethyleneglycol Ester, $\mathrm{ME}_{3}$ (5)}

A mixture of triethylene glycol monomethyl ether $(1.0 \mathrm{~g}, 6.1 \mathrm{mmol})$ and 2,2-dimethyl-1,3-dioxane4,6-dione (3, Meldrum's acid, $0.9 \mathrm{~g}, 6.2 \mathrm{mmol}$ ) was stirred under Ar atmosphere over a period of $12 \mathrm{~h}$ at $90{ }^{\circ} \mathrm{C}$. The reaction mixture was cooled to room temperature, treated with aqueous sodium carbonate solution (5\%), and washed with diethyl ether. The resulting aqueous layer was subsequently treated with dil. $\mathrm{HCl}(2.0 \mathrm{~N})$ and extracted with ethyl acetate $(50 \mathrm{~mL})$. The ethyl acetate solution was dried over $\mathrm{Na}_{2} \mathrm{SO}_{4}$ and concentrated on rotary evaporator to give the product $\mathrm{ME}_{3}(\mathbf{5})$ in $90 \%$ yield $\left(1.37\right.$ g). Spectroscopic data: FT-IR (KBr) $v_{\max } 3056$ (w), 2880 (w), 2817 (w), 1728 (vs), 1455 (w), 1394 (m), 1318 (s), 1251 (s), 1134 (vs), 1098 (vs), 1034 (m), 952 (w), 847 (s), and 753 (m) cm ${ }^{-1}$; ${ }^{1} \mathrm{H}-\mathrm{NMR}\left(500 \mathrm{MHz}, \mathrm{CDCl}_{3}, \mathrm{ppm}\right) \delta 9.65(\mathrm{~s}, \mathrm{br}, 1 \mathrm{H}), 4.32$ (t, $\left.J=4.50 \mathrm{~Hz}, 2 \mathrm{H}\right), 3.70$ (t, $J=4.50 \mathrm{~Hz}$, $2 \mathrm{H}), 3.65-3.55(\mathrm{~m}, 8 \mathrm{H}), 3.42(\mathrm{~s}, 3 \mathrm{H})$, and $3.41(\mathrm{~s}, 2 \mathrm{H})$. 
3.3.3. Synthesis of Methoxyethyleneglycol-[ $N, N^{\prime}, N, N, N, N$-hexapropyl-hexa(aminoethyl)amino]malonamide Ester, $\mathrm{ME}_{1} \mathrm{~N}_{6} \mathrm{C}_{3}(7)$

A mixture of malonic acid methoxyethyleneglycol ester $4(0.5 \mathrm{~g}, 3.08 \mathrm{mmol})$, $N$-hydroxysuccinamide $(0.35 \mathrm{~g}, 3.08 \mathrm{mmol})$, and $N, N^{\prime}$-dicyclohexyl carbodiimide (DCC, $0.63 \mathrm{~g}$, $4.0 \mathrm{mmol})$ in anyhydrous tetrahydrofuran $(20 \mathrm{~mL})$ were stirred under $\mathrm{N}_{2}$ atmosphere over a period of $12 \mathrm{~h}$ at ambient temperature. The resulting white solids of $N, N^{\prime}$-dicyclohexyl urea byproduct were filtered off and the filtrate was taken into a second round-bottom flask containing $N, N^{\prime}, N, N, N, N$ hexapropyl-hexa(aminoethyl)amine 6 (1.49 $\mathrm{g}, 3.08 \mathrm{mmol})$. The mixture was stirred under $\mathrm{N}_{2}$ atmosphere for an additional period of $12 \mathrm{~h}$. At the end of the reaction, the solvent was removed on rotavap. To this residue, ice-cold hexane-dichloromethane $(1: 1,15 \mathrm{~mL})$ was added followed by filtration to remove further white solids of $N$-hydroxysuccinamide. The filtrate was washed with aqueous sodium carbonate $(5 \%)$ solution $(10 \mathrm{~mL})$. The organic layer was then dried and concentrated to give $\mathrm{ME}_{1} \mathrm{~N}_{6} \mathrm{C}_{3}$ (7) as yellow liquid in $82 \%$ yield (1.59 g). Spectroscopic data: ESI-MS (rel. intensity) $m / z$ 568, $570\left(\mathrm{M}-\mathrm{CH}_{3} \mathrm{OCH}_{2} \mathrm{CH}_{2}, 75 \%\right), 571,629\left(\mathrm{M}^{+}\right), 630\left(\mathrm{MH}^{+}, 100 \%\right), 631,646,666,670,688$, $700,715\left[\mathrm{MH}^{+}+\mathrm{CH}_{2} \mathrm{CH}_{2} \mathrm{~N}\left(\mathrm{CH}_{2} \mathrm{CH}_{2} \mathrm{CH}_{3}\right), 48 \%\right], 716,755,757,772,773,775,800\left(\mathrm{MH}+2\left[\mathrm{CH}_{2} \mathrm{CH}_{2} \mathrm{~N}\right.\right.$ $\left.\left.\left(\mathrm{CH}_{2} \mathrm{CH}_{2} \mathrm{CH}_{3}\right)\right], 15 \%\right), 801,832,860,1150,1210,1212$ (the dimer mass $\left.-\mathrm{CH}_{3} \mathrm{OCH}_{2}\right), 1236$, and 1252 (from the dimer ion mass); FT-IR (KBr) $v_{\max } 3259$ (w), 2956 (vs), 2932 (s), 2872 (m), 2808 (m), 1742 (s), 1660 (s), 1550 (w), 1459 s), 1273 (m), 1128 (m), 1074 (s), 1031 (m), and 742 (w) cm ${ }^{-1}$; ${ }^{1} \mathrm{H}-\mathrm{NMR}$ (500 MHz, $\left.\mathrm{CDCl}_{3}, \mathrm{ppm}\right) \delta 4.29(\mathrm{t}, J=4.25 \mathrm{~Hz}, 2 \mathrm{H}), 3.61(\mathrm{t}, J=4.25 \mathrm{~Hz}, 2 \mathrm{H}), 3.40(\mathrm{~s}, 3 \mathrm{H}), 3.34-3.32$ $(\mathrm{m}, 4 \mathrm{H}), 2.38-2.57(\mathrm{~m}, 30 \mathrm{H}), 1.47-1.44(\mathrm{~m}, 12 \mathrm{H})$, and $0.90-0.87(\mathrm{t}, J=7.15 \mathrm{~Hz}, 18 \mathrm{H}) ;{ }^{13} \mathrm{C}-\mathrm{NMR}$ $\left(500 \mathrm{MHz}, \mathrm{CDCl}_{3}, \mathrm{ppm}\right) \delta 168.78(-\mathbf{C}=\mathrm{O}), 164.65(\mathrm{O}=\mathbf{C}-\mathrm{NH}-), 70.06,64.15,58.90,57.35,57.29$, $57.13,56.83$ (4C), 56.72, 56.55, 53.65, 53.00, 52.81, 52.58, 52.46, 52.00, 41.60, 37.58, 20.41, 20.39, 20.37, 20.32 (2C), 20.18, 11.90 (3C), 11.87 (2C), and 11.74.

3.3.4. Synthesis of Methoxy-tri(ethyleneglycol)-[ $\left[N, N^{\prime}, N, N, N, N\right.$-hexapropyl-hexa(aminoethyl)-amino]malonamide Ester, $\mathrm{ME}_{3} \mathrm{~N}_{6} \mathrm{C}_{3}(\mathbf{8})$

A mixture of malonic acid methoxytriethyleneglycol ester 5 (1.0 g, $4.0 \mathrm{mmol})$, $N$-hydroxysuccinamide $(0.45 \mathrm{~g}, 4.0 \mathrm{mmol})$, and $N, N^{\prime}$-dicyclohexyl carbodiimide $(0.82 \mathrm{~g}, 4.0 \mathrm{mmol})$ in anyhydrous tetrahydrofuran $(30 \mathrm{~mL})$ were stirred under $\mathrm{N}_{2}$ atmosphere for a period of $12 \mathrm{~h}$ at ambient temperature. The resulting white solids of $N, N^{\prime}$-dicyclohexyl urea byproduct were filtered off and the filtrate was taken into a second round-bottom flask containing $N, N^{\prime}, N, N, N, N$-hexapropylhexa(aminoethyl)amine 6 (1.94 g, $3.9 \mathrm{mmol})$. The mixture was stirred under $\mathrm{N}_{2}$ atmosphere for an additional period of $12 \mathrm{~h}$. At the end of the reaction, the solvent was removed on rotavap. To this residue, ice-cold hexane-dichloromethane $(1: 1,20 \mathrm{~mL})$ was added followed by filtration to remove white solids of $\mathrm{N}$-hydroxysuccinamide. The filtrate was washed with aqueous sodium carbonate $(5 \%)$ solution $(10 \mathrm{~mL})$. The organic phase was then dried and concentrated to give $\mathrm{ME}_{3} \mathrm{~N}_{6} \mathrm{C}_{3}(\mathbf{8})$ as yellow liquid in $80 \%$ yield $(2.29 \mathrm{~g}$ ). Spectroscopic data: ESI-MS (rel. intensity) $\mathrm{m} / \mathrm{z} 512,568$ $\left[\mathrm{M}-\mathrm{CH}_{3} \mathrm{O}\left(\mathrm{CH}_{2} \mathrm{CH}_{2} \mathrm{O}\right)_{2} \mathrm{CH}_{2}, 65 \%\right], 660\left(\mathrm{M}-\mathrm{CH}_{3} \mathrm{OCH}_{2} \mathrm{CH}_{2}, 55 \%\right), 716,718\left(\mathrm{MH}^{+}, 100 \%\right), 734$, 776, $803\left[\mathrm{MH}^{+}+\mathrm{CH}_{2} \mathrm{CH}_{2} \mathrm{~N}\left(\mathrm{CH}_{2} \mathrm{CH}_{2} \mathrm{CH}_{3}\right)\right.$ from the dimer mass, 46\%], 819, 860, 888 $\left(\mathrm{MH}^{+}+2\left[\mathrm{CH}_{2} \mathrm{CH}_{2} \mathrm{~N}\left(\mathrm{CH}_{2} \mathrm{CH}_{2} \mathrm{CH}_{3}\right)\right]\right.$ from the dimer mass, 8\%), 944, 951, 1008, 1090, 1226 (the dimer 
mass-[MeO(EG) $\left.\left.{ }_{3}-\mathrm{CO}\right], 3 \%\right), 1238,1282,1340,1430$, and 1434 (the dimer ion); FT-IR (KBr) $v_{\max }$ 3328 (w), 2952 (m), 2928 (m), 2862 (m), 2805 (m), 1736 (vs), 1667 (s), 1533 (m), 1456 (m), 1400 (m), 1379 (m), 1245 (m), 1104 (vs), 1032 (w), 938 (w), and $732(\mathrm{~m}) \mathrm{cm}^{-1} ;{ }^{1} \mathrm{H}-\mathrm{NMR}$ (500 MHz, CDCl 3 , ppm) $\delta 4.22(\mathrm{t}, J=4.68 \mathrm{~Hz}, 2 \mathrm{H}), 3.65(\mathrm{t}, J=4.68 \mathrm{~Hz}, 2 \mathrm{H}), 3.58-3.60(\mathrm{~m}, 6 \mathrm{H}), 3.48(\mathrm{t}, J=4.60 \mathrm{~Hz}, 2 \mathrm{H})$, $3.32(\mathrm{~s}, 5 \mathrm{H}), 3.26(\mathrm{~s}, \mathrm{br}, 2 \mathrm{H}), 2.31-2.48(\mathrm{~m}, 30 \mathrm{H}), 1.40-1.38(\mathrm{~m}, 12 \mathrm{H})$, and $0.82-0.79(\mathrm{t}, J=6.95 \mathrm{~Hz}$, $18 \mathrm{H}) ;{ }^{13} \mathrm{C}-\mathrm{NMR}\left(500 \mathrm{MHz}, \mathrm{CDCl}_{3}, \mathrm{ppm}\right) \delta 168.83(-\mathbf{C}=\mathrm{O}), 164.70(\mathrm{O}=\mathbf{C}-\mathrm{NH}-), 71.86(2 \mathrm{C}), 70.53$, $70.51,68.74,64.30,58.95,57.32$ (2C), 57.14, 56.83 (4C), 56.72, 56.53, 53.64, 53.41, 52.98 (2C), $52.80,52.45,41.54,37.55,20.40,20.37,20.31$ (3C), 20.24, 11.91 (3C), 11.88 (2C), and 11.76.

3.3.5. Synthesis of Methoxyethyleneglycol-[ $\left[N, N^{\prime}, N, N, N, N\right.$-hexapropyl-hexa(aminoethyl)amino]malonamide Ester Quaternary Methyl Ammonium Salt, $\mathrm{ME}_{1} \mathrm{~N}_{6}{ }^{+} \mathrm{C}_{3}(\mathbf{9})$

A solution of malonamide ester $7(1.0 \mathrm{~g}, 1.6 \mathrm{mmol})$ in anhydrous chloroform-DMF (10:1) was added iodomethane $\left(6.0 \mathrm{~mL}\right.$, excess, in portions) and stirred at $45{ }^{\circ} \mathrm{C}$ for a period of 3.0 days. At the end of quaternization, the solvent was evaporated to afford $\mathrm{ME}_{1} \mathrm{~N}_{6}{ }^{+} \mathrm{C}_{3}$ (9) in $94 \%$ yield (2.0 g). Spectroscopic data: FT-IR (KBr) $v_{\max } 3444$ (s), 3236 (m), 2968 (vs), 2937 (vs), 2877 (m), 1735 (s), 1667 (s), 1536 (m), 1459 (vs), 1331 (w), 1126 (m), 1032 (m), 948 (m), 872 (w), 750 (vs), and 661 (m) $\mathrm{cm}^{-1}$; ${ }^{1} \mathrm{H}-\mathrm{NMR}\left(500 \mathrm{MHz}, \mathrm{DMSO}-d_{6}, \mathrm{ppm}\right) \delta 3.80-4.25(\mathrm{~m}, \mathrm{br}, 16 \mathrm{H}), 3.22-3.80(\mathrm{~m}, \mathrm{br}, 41 \mathrm{H})$, $1.50-1.85(\mathrm{~m}, \mathrm{br}, 12 \mathrm{H})$, and 0.88-0.99 (m, br, 18H); ${ }^{13} \mathrm{C}-\mathrm{NMR}\left(500 \mathrm{MHz}, \mathrm{DMSO}-d_{6}, \mathrm{ppm}\right) \delta 168.09$ $(-\mathbf{C}=\mathrm{O}), 166.69(\mathrm{O}=\mathbf{C}-\mathrm{NH}-), 79.90,79.70,70.01,64.28$ (4C), 63.59 (5C), 58.54, 55.54 (4C), 53.96 (2C), 49.37 (3C), 48.85 (2C), 42.62, 16.27 (2C), 15.95 (4C), 10.94 (2C), $10.82(2 \mathrm{C})$, and 10.72 (2C) (one peak is covered by DMSO peaks). Anal. Calcd for $\mathrm{C}_{34} \mathrm{H}_{72} \mathrm{~N}_{6} \mathrm{O}_{4} \cdot 4.5 \mathrm{CH}_{3} \mathrm{I} \cdot 2 \mathrm{H}_{2} \mathrm{O}$ (based on $90 \%$ quarternization on average): $\mathrm{C}, 35.47 ; \mathrm{H}, 6.92 ; \mathrm{N}, 6.45 ; \mathrm{I}, 43.80 ; \mathrm{O}, 7.36 \%$. Found: $\mathrm{C}, 34.72 ; \mathrm{H}, 6.82$; $\mathrm{N}, 6.46 ; \mathrm{I}, 42.31 \%$.

3.3.6. Synthesis of Methoxy-tri(ethyleneglycol)-[N, $N^{\prime}, N, N, N, N$-hexapropyl-hexa(aminoethyl)-amino]malonamide Ester Quaternary Methyl Ammonium Salt, $\mathrm{ME}_{3} \mathrm{~N}_{6}{ }^{+} \mathrm{C}_{3}(\mathbf{1 0})$

A solution of malonamide ester $8(0.50 \mathrm{~g}, 0.70 \mathrm{mmol})$ in anhydrous chloroform-DMF (10:1) was added iodomethane $\left(3.0 \mathrm{~mL}\right.$, excess, in portions) and stirred at $45{ }^{\circ} \mathrm{C}$ for a period of 3.0 days. At the end of quaternization, the solvent was evaporated to afford $\mathrm{ME}_{3} \mathrm{~N}_{6}{ }^{+} \mathrm{C}_{3}$ (10) in $92 \%$ yield $(0.92 \mathrm{~g})$. Spectroscopic data: ESI-MS (rel. intensity) $m / z 448$ (100\%), 503, 588 (40\%), $731\left(\mathrm{M}^{+}-5 \mathrm{I}-4 \mathrm{CH}_{3}, 6 \%\right)$, 760, 815, 872, $873\left(\mathrm{M}^{+}-4 \mathrm{I}-3 \mathrm{CH}_{3}, 8 \%\right), 930,1014,1016\left(\mathrm{M}^{+}-3 \mathrm{I}-2 \mathrm{CH}_{3}, 13 \%\right), 1074,1099,1157$ $\left(\mathrm{M}^{+}-2 \mathrm{I}-\mathrm{CH}_{3}, 37 \%\right), 1198,1216,1299,1300\left(\mathrm{M}^{+}-\mathrm{I}, 22 \%\right), 1385,1391,1392,1442,1443$, and 1444 $\left(\mathrm{M}^{+}+\mathrm{H}_{2} \mathrm{O}\right)$; FT-IR (KBr) $v_{\max } 3436$ (vs), 3255 (m), 3006 (m), 2968 (s), 2935 (s), 2877 (m), 1736 (s), 1665 (s), 1634 (s), 1545 (w), 1459 (s), 1383 (w), 1351 (w), 1332 (w), $1271(\mathrm{w}), 1200$ (m), 1110 (s), $1034(\mathrm{~m}), 950(\mathrm{~m}), 877(\mathrm{w}), 757(\mathrm{w})$, and $600(\mathrm{~m}) \mathrm{cm}^{-1} ;{ }^{1} \mathrm{H}-\mathrm{NMR}$ (500 MHz, DMSO- $\left.d_{6}, \mathrm{ppm}\right) \delta$ 3.80-4.25 (m, br, 16H), 2.90-3.80 (m, br, 49H), 1.50-1.80 (m, br, 12H), and 0.85-0.99 (m, br, 18H); ${ }^{13} \mathrm{C}-\mathrm{NMR}\left(500 \mathrm{MHz}, \mathrm{DMSO}-d_{6}, \mathrm{ppm}\right) \delta 168.13(-\mathrm{C}=\mathrm{O}), 166.69(\mathrm{O}=\mathrm{C}-\mathrm{NH}-), 71.72,70.23,70.18$, 70.03, 68.57, 63.56 (9C), 54.79 (6C), 49.05 (5C), 42.62, 16.18 (2C), 15.97 (4C), 10.95 (2C), 10.82 (3C), and 10.70 (one peak is covered by DMSO peaks). Anal. Calcd for $\mathrm{C}_{38} \mathrm{H}_{80} \mathrm{~N}_{6} \mathrm{O}_{6} \cdot 4 \mathrm{CH}_{3} \mathrm{I} \cdot 3 \mathrm{H}_{2} \mathrm{O}$ (based on $80 \%$ quarternization on average): C, 37.67; H, 7.38; N, 6.28; I, 37.91; O, 10.76\%. Found: C, 36.10; H, 7.03; N, 6.81; I, 37.90\%. 
3.3.7. Synthesis of Pentacationic Methoxyethyleneglycol-(20-oxo-4,7,10,13,16-pentapropyl-4,7,10,13, 16,19-hexaaza-nonadecan-19-yl)[60]fullerenyl Malonate Quaternary Methyl Ammonium Salt, $\mathrm{C}_{60}\left(>\mathrm{ME}_{1} \mathrm{~N}_{6}^{+} \mathrm{C}_{3}\right)(\mathbf{1})$

Finely divided [60]fullerene ( $0.94 \mathrm{~g}, 1.30 \mathrm{mmol}$, more than two-fold excess to allow the formation of monoadduct only) was taken into a round bottom flask and added anhydrous toluene (700 $\mathrm{mL})$ under nitrogen. The solution was stirred for $12 \mathrm{~h}$ at ambient temperature to ensure complete dissolution of $\mathrm{C}_{60}$. To the resulting purple-colored solution added carbon tetrabromide $(0.19 \mathrm{~g}, 0.57 \mathrm{mmol})$ followed by a solution of the compound $9(0.70 \mathrm{~g}, 0.52 \mathrm{mmol})$ in anhydrous DMF $(100 \mathrm{~mL})$. The solution mixture was stirred for an additional $30 \mathrm{~min}$ and added slowly 1.8-diazabicyclo[5.4.0]-undec7-ene (DBU, $0.17 \mathrm{~g}, 1.15 \mathrm{mmol}$ ) over a period of $45 \mathrm{~min}$. The color of solution slowly turns into brown in a reaction period of $8.0 \mathrm{~h}$. The solution was then concentrated on rotavap to roughly $100 \mathrm{~mL}$. Upon the addition of methanol to this concentrated solution, the crude product was precipitated as brown solids which were collected via centrifugation. Unreacted $\mathrm{C}_{60}$ in the crude solids was removed by repeated washings with toluene $(5 \times 100 \mathrm{~mL})$ until no color in the washing solution or filtrate. The remaining product of $\mathrm{C}_{60}\left(>\mathrm{ME}_{1} \mathrm{~N}_{6}{ }^{+} \mathrm{C}_{3}\right)$ (1) was obtained as brown solids in 55\% yield $(0.59 \mathrm{~g}$, after recovered $\mathrm{C}_{60}$ ). Spectroscopic data: FT-IR (KBr) $v_{\max } 3383(\mathrm{vs}), 2963(\mathrm{~m}), 2932(\mathrm{~m}), 2870(\mathrm{~m}), 2814$ (w), 1739 (s), 1686 (s), 1625 (s), 1455 (vs), 1426 (s), 1373 (w), 1240 (w), 1067 (s), 1031 (s), 947 (m), $728(\mathrm{~m}), 575(\mathrm{~m})$, and 525 (vs, a characteristic band of $\mathrm{C}_{60}$ monoadduct) $\mathrm{cm}^{-1}$; UV-Vis (DMF, cutoff at $\left.268 \mathrm{~nm}, 2.0 \times 10^{-5} \mathrm{M}\right) \lambda_{\max } 323 \mathrm{~nm}$ (shoulder peak); ${ }^{1} \mathrm{H}-\mathrm{NMR}$ [500 MHz, DMSO- $d_{6}$-toluene- $d_{8}$ (2:1), ppm] $\delta 3.80-4.25$ (m, br, $16 \mathrm{H}), 2.90-3.80$ (m, br, 39H), 1.50-1.80 (m, br, 12H), and 0.88-0.99 $(\mathrm{m}, \mathrm{br}, 18 \mathrm{H})$. We found that electronic interferences of iodide anions in a high quantity with the fullerene cage or possible partial electron-transfer events prohibited the detection of fullerenyl carbon peaks (in low signal intensity).

3.3.8. Synthesis of Pentacationic Methoxy-tri(ethyleneglycol)-(20-oxo-4,7,10,13,16-pentapropyl4,7,10,13,16,19-hexaaza-nonadecan-19-yl)[60]fullerenyl Malonate Methyl Quaternary Ammonium Salt, $\mathrm{C}_{60}\left(>\mathrm{ME}_{3} \mathrm{~N}_{6}^{+} \mathrm{C}_{3}\right)(2)$

Finely divided [60]fullerene (1.0 g, $1.40 \mathrm{mmol}$, more than two-fold excess to allow the formation of monoadduct only) was taken into a round bottom flask and added anhydrous toluene $(700 \mathrm{~mL})$ under nitrogen. The solution was stirred for $12 \mathrm{~h}$ at ambient temperature to ensure complete dissolution of $\mathrm{C}_{60}$. To the resulting purple-colored solution added carbon tetrabromide $(0.17 \mathrm{~g}, 0.51 \mathrm{mmol})$ followed by a solution of compound $10(0.65 \mathrm{~g}, 0.45 \mathrm{mmol})$ in anhydrous DMF $(100 \mathrm{~mL})$. The solution mixture was stirred for an additional $30 \mathrm{~min}$ of stirring and added slowly 1.8-diazabicyclo[5.4.0]-undec-7-ene (DBU, $0.15 \mathrm{~g}, 0.98 \mathrm{mmol}$ ) over a period of $45 \mathrm{~min}$. The color of solution slowly turns into brown in a reaction period of $8 \mathrm{~h}$. The solution was then concentrated on rotavap to roughly $100 \mathrm{~mL}$. Upon the addition of methanol to this concentrated solution, the crude product was precipitated as brown solids which were collected via centrifugation. Unreacted $\mathrm{C}_{60}$ in the crude solids was removed by repeated washings with toluene $(5 \times 100 \mathrm{~mL})$ until no color in the washing solution or filtrate. The remaining product of $\mathrm{C}_{60}\left(>\mathrm{ME}_{3} \mathrm{~N}_{6}{ }^{+} \mathrm{C}_{3}\right)(2)$ was obtained as brown solids in $50 \%$ yield $(0.343 \mathrm{~g}$, after recovered $\mathrm{C}_{60}$ ). Spectroscopic data: FT-IR (KBr) $v_{\max } 3433$ (vs), 3262 (s), 2963 (m), 2925 (m), 2868 (m), 2809 
(w), 1736 (s), 1695 (m), 1630 (s), 1459 (s), 1384 (w), 1197 (m), 1107 (s), 1071 (s), 938 (m), 757 (w), and 525 (s, a characteristic band of $\mathrm{C}_{60}$ monoadduct) $\mathrm{cm}^{-1}$; UV-Vis (DMF, cutoff at $268 \mathrm{~nm}, 2.0 \times 10^{-5} \mathrm{M}$ ) $\lambda_{\max } 323 \mathrm{~nm}$ (shoulder peak); ${ }^{1} \mathrm{H}-\mathrm{NMR}$ [500 MHz, DMSO- $d_{6}$-toluene- $\left.d_{8}(2: 1), \mathrm{ppm}\right] \delta 3.80-4.20(\mathrm{~m}$, br, $16 \mathrm{H}), 2.90-3.80(\mathrm{~m}, \mathrm{br}, 47 \mathrm{H}), 1.50-1.75(\mathrm{~m}, \mathrm{br}, 12 \mathrm{H})$, and $0.88-0.99$ (m, br, $18 \mathrm{H})$. We found that electronic interferences of iodide anions in a high quantity with the fullerene cage or possible partial electron-transfer events prohibited the detection of fullerenyl carbon peaks (in low signal intensity).

\subsubsection{Synthesis of tert-Butyl(2-methoxyethyl)malonate, $\mathrm{ME}_{1}\left(t-\mathrm{C}_{4}\right)(\mathbf{1 1})$}

A mixture of malonic acid methoxyethyleneglycol ester 4 (1.0 g, $6.16 \mathrm{mmol}), 2$-methyl-2-propanol (0.54 g, $7.39 \mathrm{mmol}$ ), and $N, N^{\prime}$-dicyclohexyl carbodiimide (DCC, $1.27 \mathrm{~g}, 6.16 \mathrm{mmol}$ ) in anyhydrous dichloromethane $(20 \mathrm{~mL})$ were stirred under atmospheric pressure of $\mathrm{N}_{2}$ over a period of $8.0 \mathrm{~h}$ at ambient temperature. The resulting white solid of $N, N^{\prime}$-dicyclohexyl urea was filtered and the filtrate was washed with aqueous sodium carbonate solution $(5 \%, 10 \mathrm{~mL})$. The organic layer was then dried over sodium sulfate and concentrated on rotavap to give $\mathrm{ME}_{1}\left(t-\mathrm{C}_{4}\right)(\mathbf{1 1})$ in $74 \%$ yield $(1.0 \mathrm{~g})$ as light yellow liquid. Spectroscopic data: FT-IR (KBr) $v_{\max } 2980$ (w), 2930 (w), $2880(\mathrm{w}), 2824(\mathrm{w}), 1748(\mathrm{~s})$, 1726 (vs), 1455 (w), 1406 (w), 1393 (w), 1368 (m), 1330 (m), 1281 (m), 1250 (m), 1199 (m), 1127 (vs), 1100 (m), 1037 (s), $966(\mathrm{~m}), 864(\mathrm{~m}), 838(\mathrm{~m}), 759$ (w), and $738(\mathrm{w}) \mathrm{cm}^{-1} ;{ }^{1} \mathrm{H}-\mathrm{NMR}$ (500 MHz, $\left.\mathrm{CDCl}_{3}, \mathrm{ppm}\right) \delta 4.27(\mathrm{t}, J=3.94 \mathrm{~Hz}, 2 \mathrm{H}), 3.56(\mathrm{t}, J=3.94 \mathrm{~Hz}, 2 \mathrm{H}), 3.34(\mathrm{~s}, 3 \mathrm{H}), 3.29\left(\mathrm{~s}, 2 \mathrm{H}, \mathrm{H}_{\alpha}\right)$, and $1.43(\mathrm{~s}, 9 \mathrm{H})$.

\subsubsection{Synthesis of tert-Butyl(methoxy-triethyleneglycol)malonate, $\mathrm{ME}_{3}\left(t-\mathrm{C}_{4}\right)(\mathbf{1 2})$}

A mixture of malonic acid methoxytriethyleneglycol ester 5 (3 g, $11.98 \mathrm{mmol}$ ), 2-methyl-2propanol (1.06 g, $14.38 \mathrm{mmol})$, and $N, N^{\prime}$-dicyclohexyl carbodiimide $(2.47 \mathrm{~g}, 11.98 \mathrm{mmol})$ in anyhydrous dichloromethane $(20 \mathrm{~mL})$ were stirred under atmospheric pressure of $\mathrm{N}_{2}$ over a period of $8.0 \mathrm{~h}$ at ambient temperature. The resulting white solid of $N, N^{\prime}$-dicyclohexyl urea was filtered and the filtrate was washed with aqueous sodium carbonate solution $(5 \%, 10 \mathrm{~mL})$. The organic layer was then dried over sodium sulfate and concentrated on rotavap to give $\mathrm{ME}_{3}\left(t-\mathrm{C}_{4}\right)(\mathbf{1 2})$ in $77 \%$ yield $(2.85 \mathrm{~g})$ as light yellow liquid. Spectroscopic data: FT-IR (KBr) $v_{\max } 2973$ (w), 2930 (w), 2876 (w), $2817(\mathrm{w})$, 1748 (s), 1727 (vs), 1455 (w), 1393 (w), 1368 (m), 1330 (m), 1282 (m), 1250 (m), 1198 (m), 1134 (vs), 1104 (vs), 1040 (m), $966(\mathrm{~m}), 864(\mathrm{~m}), 759(\mathrm{w})$, and $735(\mathrm{w}) \mathrm{cm}^{-1} ;{ }^{1} \mathrm{H}-\mathrm{NMR}\left(500 \mathrm{MHz}, \mathrm{CDCl}_{3}, \mathrm{ppm}\right)$ $\delta 4.26(\mathrm{t}, J=4.50 \mathrm{~Hz}, 2 \mathrm{H}), 3.68(\mathrm{t}, J=4.50 \mathrm{~Hz}, 2 \mathrm{H}), 3.63(\mathrm{~m}, 6 \mathrm{H}), 3.52(\mathrm{t}, J=4.50 \mathrm{~Hz}, 2 \mathrm{H}), 3.35$ (s, 3H), $3.29(\mathrm{~s}, 2 \mathrm{H}, \alpha-\mathrm{H})$, and $1.44(\mathrm{~s}, 9 \mathrm{H})$.

\subsubsection{Synthesis of tert-Butyl(2-methoxyethyl)[60]fullerenyl Malonate, $\mathrm{C}_{60}\left[>\mathrm{ME}_{1}\left(t-\mathrm{C}_{4}\right)\right](\mathbf{1 3})$}

Finely divided [60]fullerene $(1.23 \mathrm{~g}, 1.70 \mathrm{mmol})$ was taken into a round bottom flask and added anhydrous toluene $(850 \mathrm{~mL})$ and 1,2-dichlorobenzene $(30 \mathrm{~mL})$ under nitrogen. The solution was stirred for $1.0 \mathrm{~h}$ at ambient temperature to ensure complete dissolution of $\mathrm{C}_{60}$. To the resulting purplecolored solution was added carbon tetrabromide $(0.50 \mathrm{~g}, 1.51 \mathrm{mmol})$ followed by a solution of tertbutyl(2-methoxyethyl)malonate $(\mathbf{1 1}, 0.30 \mathrm{~g}, 1.37 \mathrm{mmol})$ in anhydrous toluene $(10 \mathrm{~mL})$. The solution mixture was stirred for an additional $30 \mathrm{~min}$ and added slowly 1.8-diazabicyclo[5.4.0]-undec-7-ene 
(DBU, $0.44 \mathrm{~g}, 2.88 \mathrm{mmol}$ ) over a period of $1.0 \mathrm{~h}$. The color of solution slowly turned into brown in a reaction period of $12 \mathrm{~h}$. The solution was then concentrated on a rotavap. The resulting crude product was purified using column chromatography with silica gel as the stationary phase and toluene-ethyl acetate (20:1) as eluent, giving the isolation of tert-butyl(2-methoxyethyl)[60]fullerenyl malonate (13), $\mathrm{C}_{60}\left[>\mathrm{ME}_{1}\left(t-\mathrm{C}_{4}\right)\right]$, as brown solids in 78\% yield (1.00 g). Spectroscopic data: FT-IR (KBr) $v_{\max } 3442$ (br, s), 2972 (w), 2917 (w), 2873 (w), 2814 (w), 1739 (vs), 1645 (m), 1426 (m), 1390 (w), 1366 (m), 1268 (s), 1232 (vs), 1179 (m), 1151 (s), 1110 (m), 1059 (m) 1026 (m), 828 (w), 738 (w), 704 (w), $577(\mathrm{~m}), 551(\mathrm{~m})$, and 525 (vs, a characteristic band of $\mathrm{C}_{60}$ monoadduct) $\mathrm{cm}^{-1} ;{ }^{1} \mathrm{H}-\mathrm{NMR}(500 \mathrm{MHz}$, toluene- $\left.d_{8}, \mathrm{ppm}\right) \delta 4.28(\mathrm{t}, J=4.55 \mathrm{~Hz}, 2 \mathrm{H}), 3.26(\mathrm{t}, J=4.55 \mathrm{~Hz}, 2 \mathrm{H}), 3.06(\mathrm{~s}, 3 \mathrm{H})$, and $1.55(\mathrm{~s}, 9 \mathrm{H})$; ${ }^{13} \mathrm{C}-\mathrm{NMR}\left(500 \mathrm{MHz}\right.$, toluene- $\left.d_{8}, \mathrm{ppm}\right) \delta 163.45$ (O=C-O-tert-butyl), $161.86(\mathrm{O}=\mathrm{C}-\mathrm{O}-), 145.89(2 \mathrm{C})$, 145.53 (2C), 145.22 (2C), 145.13 (2C), 145.06 (3C), 144.95 (2C), 144.93 (2C), 144.60 (2C), 144.59 (2C), 144.46 (3C), 144.45 (4C), 143.71 (2C), 143.68 (2C), 142.91 (C), 142.89 (C), 142.83 (2C), 142.81 (3C), 142.80 (3C), 142.74 (2C), 142.03 (2C), 142.02 (2C), 141.76 (2C), 141.74 (2C), 140.74 (2C), 140.68 (2C), 139.37 (2C), 138.93 (2C), 84.13, 72.07 (fullerenyl sp ${ }^{3}$ carbons, 2C), 69.74, 65.49, $58.00,53.45$, and $27.49(3 \mathrm{C})$.

\subsubsection{Synthesis of tert-Butyl(methoxy-triethyleneglycol)[60]fullerenyl Malonate, $\mathrm{C}_{60}\left[>\mathrm{ME}_{3}\left(t-\mathrm{C}_{4}\right)\right](\mathbf{1 4})$}

Finely divided [60]fullerene (1.86 g, $2.59 \mathrm{mmol})$ was taken into a round bottom flask and added anhydrous toluene $(850 \mathrm{~mL})$ and 1,2-dichlorobenzene $(50 \mathrm{~mL})$ under nitrogen. The solution was stirred for $1.0 \mathrm{~h}$ at ambient temperature to ensure complete dissolution of $\mathrm{C}_{60}$. To the resulting purplecolored solution was added carbon tetrabromide $(0.75 \mathrm{~g}, 2.27 \mathrm{mmol})$ followed by a solution of tertbutyl(methoxy-triethyleneglycol)malonate $12(0.63 \mathrm{~g}, 2.07 \mathrm{mmol})$ in anhydrous toluene $(10 \mathrm{~mL})$. The solution mixture was stirred for an additional $30 \mathrm{~min}$ and added slowly 1.8-diazabicyclo[5.4.0]-undec7-ene (DBU, $0.66 \mathrm{~g}, 4.35 \mathrm{mmol}$ ) over a period of $1.0 \mathrm{~h}$. The color of solution slowly turned into brown in a reaction period of $12 \mathrm{~h}$. The solution was then concentrated on rotavap and the resulting crude product was purified by column chromatography with silica gel as the stationary phase and toluene-ethyl acetate (9:1) as eluent to afford $\mathrm{C}_{60}\left[>\mathrm{ME}_{3}\left(t-\mathrm{C}_{4}\right)\right](\mathbf{1 4})$ as brown solids in $75 \%$ yield $(1.60 \mathrm{~g})$. Spectroscopic data: FT-IR (KBr) $v_{\max } 3421$ (br, s), 2967 (w), 2914 (w), 2864 (w), 2814 (w), 1740 (s), $1634(\mathrm{~m}), 1456(\mathrm{~m}), 1426$ (m), 1392 (m), 1368 (m), 1269 (s), 1253 (s), 1226 (s), 1180 (m), 1154 (s), $1108(\mathrm{~m}), 1029(\mathrm{~m}), 845(\mathrm{~m}), 737(\mathrm{~m}), 702(\mathrm{~m}), 669(\mathrm{~m}), 576(\mathrm{~m}), 550(\mathrm{~m})$, and $525(\mathrm{vs}) \mathrm{cm}^{-1}$; ${ }^{1} \mathrm{H}-\mathrm{NMR}\left(500 \mathrm{MHz}, \mathrm{CDCl}_{3}, \mathrm{ppm}\right) \delta 4.65(\mathrm{t}, J=4.60 \mathrm{~Hz}, 2 \mathrm{H}), 3.90(\mathrm{t}, J=4.60 \mathrm{~Hz}, 2 \mathrm{H}), 3.73(\mathrm{t}$, $J=4.60 \mathrm{~Hz}, 2 \mathrm{H}), 3.65-3.72(\mathrm{~m}, 4 \mathrm{H}), 3.56(\mathrm{t}, J=4.60 \mathrm{~Hz}, 2 \mathrm{H}), 3.39(\mathrm{~s}, 3 \mathrm{H})$, and $1.70(\mathrm{~s}, 9 \mathrm{H})$; ${ }^{13} \mathrm{C}-\mathrm{NMR}\left(500 \mathrm{MHz}, \mathrm{CDCl}_{3}, \mathrm{ppm}\right) \delta 163.95$ (O=C-O-tert-butyl), $162.16(\mathrm{O}=\mathbf{C}-\mathrm{O}-), 145.61(2 \mathrm{C})$, 145.41 (2C), 145.29 (2C), 145.25 (4C), 145.22 (2C), 145.16 (3C), 144.85 (2C), 144.71 (C), 144.69 (3C), 144.66 (2C), 144.57 (4C), 143.89 (3C), 143.09 (2C), 143.08 (2C), 143.01 (4C), 142.99 (2C), 142.97 (2C), 142.23 (2C), 142.21 (2C), 141.91 (2C), 141.90 (2C), 140.94 (2C), 140.89 (2C), 139.11 (2C), 138.92 (2C), 85.16, 71.95 (fullerenyl $\mathrm{sp}^{3}$ carbons, 2C), 71.84, 70.68, 70.67, 70.65, 68.84, 66.07, 59.10, 53.06, and 28.07 (3C). 
The compound of [60]fullerenyl malonate $13(0.5 \mathrm{~g}, 0.64 \mathrm{mmol})$ was taken into a round bottom flask containing anhydrous dichloromethane $(50 \mathrm{~mL})$ and purged with $\mathrm{N}_{2}$ for 15 minutes at ambient temperature. To this reaction mixture was added trifluoroacetic acid (30 mL, excess) and stirred for overnight at room temperature. At the end of the reaction, dichloromethane was removed on rotavap. Additional dichloromethane $(3 \times 15 \mathrm{~mL})$ was added and removed on rotavap in order to fully eliminate an excessive amount of trifluoroacetic acid. The resulting residue was then washed with diethyl ether $(2 \times 15 \mathrm{~mL})$ to afford $\mathrm{C}_{60}\left(>\mathrm{ME}_{1} \mathrm{H}\right)(\mathbf{1 5})$ as brown solids in $89 \%$ yield $(0.50 \mathrm{~g})$. Spectroscopic data: FT-IR (KBr) $v_{\max } 3670(\mathrm{br}, \mathrm{s}), 2977(\mathrm{w}), 2917(\mathrm{w}), 2878(\mathrm{w}), 2814(\mathrm{w}), 1792(\mathrm{w}), 1750(\mathrm{~s}), 1708(\mathrm{~s}), 1681$ (m), 1541 (w), 1427 (m), 1390 (w), 1366 (m), 1267 (s), 1250 (s), 1231 (s), 1186 (m), 1114 (w), 1059 (w) $1020(\mathrm{w}), 864(\mathrm{w}), 743(\mathrm{w}), 701(\mathrm{~m}), 572(\mathrm{~m}), 552(\mathrm{~m})$, and 525 (vs, a characteristic band of $\mathrm{C}_{60}$ monoadduct) $\mathrm{cm}^{-1} ;{ }^{1} \mathrm{H}-\mathrm{NMR}\left(500 \mathrm{MHz}\right.$, THF- $\left.d_{8}, \mathrm{ppm}\right) \delta 4.59(\mathrm{t}, J=4.50 \mathrm{~Hz}, 2 \mathrm{H}), 3.71(\mathrm{t}, J=4.50 \mathrm{~Hz}$, $2 \mathrm{H})$, and $3.34(\mathrm{~s}, 3 \mathrm{H}) ;{ }^{13} \mathrm{C}-\mathrm{NMR}\left[500 \mathrm{MHz}, \mathrm{THF}-d_{8}-\mathrm{CS}_{2}(2: 1), \mathrm{ppm}\right] \delta 161.62(\mathrm{O}=\mathrm{C}-\mathrm{O}-), 161.13$ $(\mathrm{O}=\mathrm{C}-\mathrm{OH}), 144.54$ (2C), 144.06 (2C), 143.53 (2C), 143.39 (2C), 143.26 (2C), 143.25 (2C), 143.19 (2C), 143.16 (2C), 142.91 (C), 142.85 (2C), 142.78 (C), 142.73 (2C), 142.70 (2C), 142.53 (4C), 141.99 (2C), 141.95 (2C), 141.14 (C), 141.12 (C), 141.10 (2C), 141.04 (4C), 140.98 (2C), 140.31 (4C), 140.07 (2C), 139.95 (2C), 138.89 (2C), 138.87 (2C), 137.87 (2C), 136.76 (2C), 70.48 (fullerenyl sp ${ }^{3}$ carbons, 2C), 68.14, 63.98, 56.30, and 51.46

3.3.14 Synthesis of 2-[60]Fullerenyl-3-(methoxy-triethyleneglycol)-3-oxopropanoic Acid, $\mathrm{C}_{60}\left(>\mathrm{ME}_{3} \mathrm{H}\right)$ (16)

The compound of [60]fullerenyl malonate $14(0.75 \mathrm{~g}, 0.73 \mathrm{mmol})$ was taken into a round bottom flask containing anhydrous dichloromethane $(50 \mathrm{~mL})$ and purged with $\mathrm{N}_{2}$ for a period of 15 minutes at ambient temperature. To this reaction mixture was added trifluoroacetic acid $(50 \mathrm{~mL})$ and stirred for overnight at room temperature. At the end of the reaction, dichloromethane was removed on rotavap. Additional dichloromethane $(3 \times 20 \mathrm{~mL})$ was added and removed on rotavap in ordered to fully eliminate an excessive amount of trifluoroacetic acid. The resulting residue was then washed with diethyl ether $(3 \times 20 \mathrm{~mL})$ to afford $\mathrm{C}_{60}\left(>\mathrm{ME}_{3} \mathrm{H}\right)(\mathbf{1 6})$ as brown solids in $87 \%$ yield $(0.62 \mathrm{~g})$. Spectroscopic data: FT-IR (KBr) $v_{\max } 3673$ (br, s), 2917 (w), $2894(\mathrm{w}), 2870(\mathrm{w}), 2814$ (w), 1788 (w), 1741 (vs), 1578 (w), 1532 (w), 1426 (m), 1383 (w), 1266 (m), 1230 (s), 1203 (m), 1180 (w), 1095 (m), $1060(\mathrm{w}) 845(\mathrm{w}), 698(\mathrm{~m}), 579(\mathrm{~m}), 549(\mathrm{~m})$, and $525(\mathrm{vs}) \mathrm{cm}^{-1} ;{ }^{1} \mathrm{H}-\mathrm{NMR}\left(500 \mathrm{MHz}, \mathrm{CDCl}_{3}, \mathrm{ppm}\right) \delta$ $4.70(\mathrm{t}, J=4.55 \mathrm{~Hz}, 2 \mathrm{H}), 3.95(\mathrm{t}, J=4.55 \mathrm{~Hz}, 2 \mathrm{H}), 3.80(\mathrm{~m}, 6 \mathrm{H}), 3.76(\mathrm{t}, J=4.60 \mathrm{~Hz}, 2 \mathrm{H})$, and 3.59 $(\mathrm{s}, 3 \mathrm{H}) ;{ }^{13} \mathrm{C}-\mathrm{NMR}\left(500 \mathrm{MHz}, \mathrm{CDCl}_{3}, \mathrm{ppm}\right) \delta 164.12(\mathrm{O}=\mathrm{C}-\mathrm{O}-), 163.79(\mathrm{O}=\mathrm{C}-\mathrm{OH}), 145.57(2 \mathrm{C})$, 145.52 (2C), 145.33 (3C), 145.32 (3C), 145.22 (4C), 145.15 (3C), 144.84 (2C), 144.75 (C), 144.68 (4C), 144.57 (2C), 144.54 (2C), 143.90 (2C), 143.88 (2C), 143.04 (3C), 142.99 (4C), 142.96 (2C), 142.23 (3C), 142.01 (2C), 141.97 (2C), 140.93 (3C), 140.92 (3C), 139.36 (2C), 138.90 (2C), 72.19, 71.88 (fullerenyl sp3 carbon, 2C), 70.89, 70.64, 70.33, 69.70, 68.34, 65.99, 58.78, and 52.51. 
3.3.15. Synthesis of Methoxyethyleneglycol-(20-oxo-4,7,10,13,16-pentapropyl-4,7,10,13,16,19hexaaza-nonadecan-19-yl)[60]fullerenyl Malonate, $\mathrm{C}_{60}\left(>\mathrm{ME}_{1} \mathrm{~N}_{6} \mathrm{C}_{3}\right)(\mathbf{1 7})$ and $\mathrm{C}_{60}\left(>\mathrm{ME}_{1} \mathrm{~N}_{6}{ }^{+} \mathrm{C}_{3}\right)\left(\mathbf{1}^{\prime}\right)$

The compound of 2-[60]fullerenyl-3-(2-methoxyethoxy)-3-oxopropanoic acid 15 (0.15 g, $0.17 \mathrm{mmol})$ was taken into a round bottom flask containing anhydrous tetrahydrofuran $(20 \mathrm{~mL})$. To this reaction mixture was added thionyl chloride $(0.03 \mathrm{~g}, 2.55 \mathrm{mmol})$ under $\mathrm{N}_{2}$ atmosphere and refluxed for a period of $2.0 \mathrm{~h}$. An excessive amount of thionyl chloride was removed on rotavap. Fresh anhydrous tetrahydrofuran $(20 \mathrm{~mL})$ was added. To this reaction solution was added slowly $N, N^{\prime}, N, N, N, N$ hexapropyl-hexa(aminoethyl)amine $6(0.08 \mathrm{~g}, 0.17 \mathrm{mmol})$ at $0{ }^{\circ} \mathrm{C}$. It was warmed gradually to room temperature and stirred at this temperature for a period of $3.0 \mathrm{~h}$. The resulting solution was concentrated on rotavap with the residue washed sequentially with hexane $(10 \mathrm{~mL})$, methanol $(2 \times 10 \mathrm{~mL})$, and toluene $(3 \times 10 \mathrm{~mL})$ to fully remove unreacted $N, N^{\prime}, N, N, N, N$-hexapropyl-hexa(aminoethyl)amine and decarboxylated $\mathrm{C}_{60}$ byproducts. A relatively pure $\mathrm{C}_{60}\left(>\mathrm{ME}_{1} \mathrm{~N}_{6} \mathrm{C}_{3}\right)$ (17) was obtained in $47 \%$ yield $(0.11 \mathrm{~g})$. It was subsequently treated with $\mathrm{CF}_{3} \mathrm{COOH}$ to result in pentacationic quaternary ammonium-trifluoroacetate salt, $\mathrm{C}_{60}\left(>\mathrm{ME}_{1} \mathrm{~N}_{6}{ }^{+} \mathrm{C}_{3}\right)\left(\mathbf{1}^{\prime}\right)$, specifically, for NMR measurements. Spectroscopic data of the compound 17: FT-IR (KBr) $v_{\max } 3670(\mathrm{br}, \mathrm{s}), 2977(\mathrm{w}), 2917(\mathrm{w}), 2878(\mathrm{w})$, 2814 (w), 1792 (w), 1750 (s), 1708 (s), 1681 (m), 1541 (w), 1427 (m), 1390 (w), 1366 (m), 1267 (s), 1250 (s), 1231 (s), 1186 (m), 1114 (w), 1059 (w), 1020 (w), 864 (w), 743 (w), 701 (m), 572 (m), 552 (m), and 525 (vs, a characteristic band of $\mathrm{C}_{60}$ monoadduct) $\mathrm{cm}^{-1}$. Spectroscopic data of the compound 1': ${ }^{1} \mathrm{H}-\mathrm{NMR}$ [500 MHz, $\mathrm{CDCl}_{3}-$ toluene- $\left.d_{8}-\mathrm{TFA}(3: 1: 1), \mathrm{ppm}\right] \delta 4.22-4.68(\mathrm{~m}, \mathrm{br}, 2 \mathrm{H}), 3.90-4.05(\mathrm{~m}$, br, 2H), 3.22-3.75 (m, br, 35H), $1.28-1.36(\mathrm{~m}, \mathrm{br}, 12 \mathrm{H})$, and $0.97(\mathrm{~m}, \mathrm{br}, 18 \mathrm{H}) ;{ }^{13} \mathrm{C}-\mathrm{NMR}$ [500 MHz, $\mathrm{CDCl}_{3}$-toluene- $d_{8}$-TFA (3:1:1), ppm] $\delta 167.72(\mathrm{O}=\mathbf{C}-\mathrm{O}-), 166.46(\mathrm{O}=\mathbf{C}-\mathrm{NH}-), 148.00(2 \mathrm{C}), 145.54$ (2C), 145.30 (2C), 145.29 (2C), 145.24 (2C), 145.14 (2C), 145.02 (2C), 144.73 (4C), 144.68 (4C), 144.53 (2C), 143.98 (2C), 143.77 (2C), 143.27 (2C), 143.11 (C), 143.04 (2C), 143.01 (2C), 142.98 (C), 142.87 (2C), 142.44 (2C), 142.22 (2C), 142.12 (2C), 142.01 (2C), 141.17 (2C), 140.98 (2C), 140.51 (2C), 137.92 (4C), 136.50 (2C), 70.47, 70.23 (fullerenyl sp ${ }^{3}$ carbon, 2C), 70.08, 69.73, 64.65, 64.40, $58.94,58.68,38.43,31.84,22.04,21.40,16.66$, and 10.10 (quaternary aminocarbon peaks were low in intensity).

3.3.16. Synthesis of Pentacationic Methoxyethyleneglycol-(20-oxo-4,7,10,13,16-pentapropyl4,7,10,13,16,19-hexaaza-nonadecan-19-yl)[60]fullerenyl Malonate Quaternary Methyl Ammonium Salt, $\mathrm{C}_{60}\left(>\mathrm{ME}_{1} \mathrm{~N}_{6}{ }^{+} \mathrm{C}_{3}\right)(\mathbf{1})$

A solution of [60]fullerenyl malonate quaternary ammonium-trifluoroacetate salt $\mathbf{1}^{\prime}$ (100 $\left.\mathrm{mg}\right)$ in chloroform $(50 \mathrm{~mL})$ was neutralized with aqueous potassium carbonate $(10 \%, 50 \mathrm{~mL})$. The resulting [60]fullerenyl malonate $\mathbf{1 7}$ was then dissolved in a mixture of anhydrous chloroform $(30 \mathrm{~mL})$ and dimethylformamide $(15 \mathrm{~mL})$. To this reaction, an excess amount of iodomethane was added in several portions over the reaction period and stirred at $45{ }^{\circ} \mathrm{C}$ for 3.0 days. At the end of the reaction, the solvent was removed on rotavap to yield pentacationic $\mathrm{C}_{60}\left(>\mathrm{ME}_{1} \mathrm{~N}_{6}{ }^{+} \mathrm{C}_{3}\right)$ (1). Spectroscopic data: MALDI-TOF-MS (sinapic acid as the matrix, rel. intensity) $m / z 673(20 \%), 697(50 \%), 721\left(\mathrm{C}_{60} \mathrm{H}^{+}\right.$, 100\%), 734 (80\%), 746 (15\%), 761 (10\%), 772 (10\%), $874\left[\mathrm{C}_{60}\left(>\mathrm{H}(\mathrm{C}=\mathrm{O}) \mathrm{NHCH}_{2} \mathrm{CH}_{2} \mathrm{~N}^{+}-\right.\right.$propylMe 2$)$, 20\%], $1442\left[\left(\mathrm{C}_{60} \mathrm{H}\right)_{2}{ }^{+}\right.$cluster $], 1565,1634,1709,1769,1851,1930\left(\mathrm{M}^{+}-\mathrm{I}^{-}\right)$; FT-IR $(\mathrm{KBr}) v_{\max } 3688$ 
(br, s), 2918 (s), 2870 (m), 2840 (m), 2807 (w), 1784 (w), 1736 (vs), 1663 (s), 1574 (w), 1433 (m), 1383 (w), 1252 (w), 1187 (m), 1163 (s), 1126 (m), 1090 (m), 1031 (s), 842 (w), 762 (w), 704 (w), 661 (w), $569(\mathrm{w})$, and 524 (vs, a characteristic band of $\mathrm{C}_{60}$ monoadduct) $\mathrm{cm}^{-1}$; UV-Vis (DMF, cutoff at $\left.268 \mathrm{~nm}, 2.0 \times 10^{-5} \mathrm{M}\right) \lambda_{\max } 323 \mathrm{~nm}$ (shoulder peak); ${ }^{1} \mathrm{H}-\mathrm{NMR}$ [500 MHz, DMSO- $d_{6}$-toluene- $d_{8}(2: 1)$, ppm] $\delta 3.80-4.25$ (m, br, 16H), 2.90-3.80 (m, br, 39H), 1.50-1.80 (m, br, 12H), and 0.88-0.99 (m, br, $18 \mathrm{H})$. We found that electronic interferences of iodide anions in a high quantity with the fullerene cage or possible partial electron-transfer events prohibited the detection of fullerenyl carbon peaks (in low signal intensity).

3.3.17. Synthesis of Pentacationic Methoxy-tri(ethyleneglycol)-(20-oxo-4,7,10,13,16-pentapropyl4,7,10,13,16,19-hexaaza-nonadecan-19-yl)[60]fullerenyl Malonate Methyl Quaternary Ammonium Salt, $\mathrm{C}_{60}\left(>\mathrm{ME}_{3} \mathrm{~N}_{6}{ }^{+} \mathrm{C}_{3}\right)(2)$

Synthesis of the compound $\mathbf{2}$ was carried out by using a similar procedure as that of $\mathbf{1}$ except methoxytriethyleneglycol ester was applied instead. Spectroscopic data: MALDI-TOF-MS (sinapic acid as the matrix, rel. intensity) $m / z 698(10 \%), 721\left(\mathrm{C}_{60} \mathrm{H}^{+}, 100 \%\right), 735\left(\mathrm{C}_{60}>\mathrm{H}_{2}, 20 \%\right), 749,773$, 782, 789, 809, $874\left[\mathrm{C}_{60}\left(>\mathrm{H}(\mathrm{C}=\mathrm{O}) \mathrm{NHCH}_{2} \mathrm{CH}_{2} \mathrm{~N}^{+}\right.\right.$-propylMe $)$], 914, 940, 995, 1027, 1054, $1278(\mathrm{w})$, $1395(\mathrm{w}), 1417(\mathrm{vw}), 1499(\mathrm{vw}), 1792(\mathrm{vw})$, and $2019\left(\mathrm{vw}, \mathrm{MH}^{+}-\mathrm{I}^{\top}\right)$; FT-IR (KBr) $v_{\max } 3424$ (vs), 2967 (m), 2925 (m), 2874 (m), 2824 (w), 1738 (s), 1681 (s), 1628 (s), 1454 (vs), 1429 (s), 1383 (m), $1064(\mathrm{~s}), 1028(\mathrm{~s}), 941(\mathrm{~m}), 727(\mathrm{~m}), 572(\mathrm{~m})$, and 524 (vs, a characteristic band of $\mathrm{C}_{60}$ monoadduct) $\mathrm{cm}^{-1}$; UV-vis (DMF, cutoff at $268 \mathrm{~nm}, 2.0 \times 10^{-5} \mathrm{M}$ ) $\lambda_{\max } 323 \mathrm{~nm}$ (shoulder peak); ${ }^{1} \mathrm{H}-\mathrm{NMR}$ [500 MHz, DMSO- $d_{6}$-toluene- $\left.d_{8}(2: 1), \mathrm{ppm}\right] \delta 3.80-4.20(\mathrm{~m}, \mathrm{br}, 16 \mathrm{H}), 2.90-3.80(\mathrm{~m}, \mathrm{br}, 47 \mathrm{H}), 1.50-1.75(\mathrm{~m}, \mathrm{br}$, $12 \mathrm{H})$, and $0.88-0.99(\mathrm{~m}, \mathrm{br}, 18 \mathrm{H})$. We found that electronic interferences of iodide anions in a high quantity with the fullerene cage or possible partial electron-transfer events prohibited the detection of fullerenyl carbon peaks (in low signal intensity).

\section{Conclusions}

We have designed and synthesized two analogous pentacationic [60]fullerenyl monoadducts, $\mathrm{C}_{60}\left(>\mathrm{ME}_{1} \mathrm{~N}_{6}{ }^{+} \mathrm{C}_{3}\right)$ (1) and $\mathrm{C}_{60}\left(>\mathrm{ME}_{3} \mathrm{~N}_{6}{ }^{+} \mathrm{C}_{3}\right)$ (2), with variation of the methoxyethyleneglycol length. Each of these derivatives bears a well-defined number of cationic charges aimed to enhance and control their ability to target pathogenic Gram-positive and Gram-negative bacterial cells. The intrinsic nature of the high charge number and increased water-solubility of the precursor arm intermediates hindered the efficiency of their reactions with a highly hydrophobic $\mathrm{C}_{60}$ cage having low compatibility in polar solvents. Furthermore, consecutive ethylamino group linkage in a structure of $N, N^{\prime}, N, N, N, N$ hexapropyl-hexa(aminoethyl)amine $\left(\mathrm{C}_{3} \mathrm{~N}_{6}\right)$ largely increased its electron-donating capability that gave complication in forming an insoluble partial charge-transfer complex with $\mathrm{C}_{60}$ during the reaction and workup procedures. After many attempts, we found a circumventive solution by the use of partially quaternized $\mathrm{C}_{3} \mathrm{~N}_{6}$ prior to the reaction with $\mathrm{C}_{60}$ coupled with the modification of $\mathrm{C}_{3} \mathrm{~N}_{6}$ arm using propyl groups, instead of methyl or ethyl groups, to provide a well-balanced hydrophobicityhydrophilicity character of pentacationic precursor intermediates and better compatibility with the $\mathrm{C}_{60}$ cage moiety. 


\section{Supplementary Materials}

Supplementary materials can be accessed at: http://www.mdpi.com/1420-3049/17/5/5225/s1.

\section{Acknowledgements}

We thank the financial support of National Institute of Health (NIH) under the grant number R01CA137108.

\section{References and Notes}

1. Dolmans, D.E.; Fukumura, D.; Jain, R.K. Photodynamic therapy for cancer. Nat. Rev. Cancer 2003, 3, 380-387.

2. Hamblin, M.R.; Hasan, T. Photodynamic therapy: A new antimicrobial approach to infectious disease? Photochem. Photobiol. Sci. 2004, 3, 436-450.

3. O'Riordan, K.; Akilov, O.E.; Hasan, T. The potential for photodynamic therapy in the treatment of localized infections. Photodiagn. Photodyn. 2005, 2, 247-262.

4. Silva, J.N.; Filipe, P.; Maziere, P.; Maziere, J.C.; Freitas, J.P.; Cine de Castro, J.P.; Santus, R. Photodynamic therapy: Dermatology and ophthalmology as main fields of current applications in clinic. Bio-Med. Mater. Eng. 2006, 16, S147-S154.

5. Sharma, S.K.; Chiang, L.Y.; Hamblin, M.R. Photodynamic therapy with fullerenes in vivo: Reality or a dream? Nanomedicine 2011, 6, 1813-1825.

6. Guldi, D.M.; Prato, M. Excited-state properties of $\mathrm{C}_{60}$ fullerene derivatives. Acc. Chem. Res. 2000, 33, 695-703.

7. Yamakoshi, Y.; Umezawa, N.; Ryu, A.; Arakane, K.; Miyata, N.; Goda, Y.; Masumizu, T.; Nagano, T. Active oxygen species generated from photoexcited fullerene $\left(\mathrm{C}_{60}\right)$ as potential medicines: $\mathrm{O}_{2}^{-\bullet}$ versus ${ }^{1} \mathrm{O}_{2}$. J. Am. Chem. Soc. 2003, 125, 12803-12809.

8. Hamblin, M.R.; O’Donnell, D.A.; Murthy, N.; Rajagopalan, K.; Michaud, N.; Sherwood, M.E.; Hasan, T. Polycationic photosensitizer conjugates: Effects of chain length and Gram classification on the photodynamic inactivation of bacteria. J. Antimicrob. Chemother. 2002, 49, 941-951.

9. Hamblin, M.R.; O’Donnell, D.A.; Murthy, N.; Contag, C.H.; Hasan, T. Rapid control of wound infections by targeted photodynamic therapy monitored by in-vivo bioluminescence imaging. Photochem. Photobiol. 2002, 75, 51-57.

10. Navarre, W.W.; Schneewind, O. Surface proteins of Gram-positive bacteria and mechanisms of their targeting to the cell wall envelope. Microbiol. Mol. Biol. Rev. 1999, 63, 174-229.

11. Scott, J.R.; Barnett, T.C. Surface proteins of Gram-positive bacteria and how they get there. Annu. Rev. Microbiol. 2006, 60, 397-423.

12. Kell, A.J.; Stewart, G.; Ryan, S.; Peytavi, R.; Boissinot, M.; Huletsky, A.; Bergeron, M.G.; Simard, B. Vancomycin-modified nanoparticles for efficient targeting and preconcentration of Gram-positive and Gram-negative bacteria. ACS Nano 2008, 2, 1777-1788.

13. Da Ros, T.; Prato, M.; Novello, F.; Maggini, M.; Banfi, E. Easy access to water-soluble fullerene derivatives via 1,3-dipolar cycloadditions of azomethine ylides to C(60). J. Org. Chem. 1996, 61, 9070-9072. 
14. Rio, Y.; Nicoud, J.F.; Rehspringer, J.L; Nierengarten, J.F. Fullerodendrimers with peripheral triethyleneglycol chains. Tetrahedron Lett. 2000, 41, 10207-10210.

15. Zhiguo, Z.; Schuster, D.I.; Wilson, S.R. Selective syntheses of novel polyether fullerene multiple adducts. J. Org. Chem. 2003, 68, 7612-7617.

16. Bianco, A.; Da Ros, T.; Prato, M.; Toniolo, C. Fullerene-based amino acids and peptides. J. Peptide Sci. 2001, 7, 208-219.

17. Cusan, C.; Da Ros, T.; Spalluto, G.; Foley, S.; Janot, J.M.; Seta, P.; Larroque, C.; Tomasini, M.C.; Antonelli, T.; Ferraro, L.; Prato, M. A new multi-charged $\mathrm{C}_{60}$ derivative: Synthesis and biological properties. Eur. J. Org. Chem. 2002, 2928-2934.

18. Braun, M.; Atalick, S.; Guldi, D.M.; Lanig, H.; Brettreich, M.; Burghardt, S.; Hatzimarinaki, M.; Ravanelli, E.; Prato, M.; van Eldik, R.; Hirsch, A. Electrostatic complexation and photoinduced electron transfer between $\mathrm{Zn}$-cytochrome c and polyanionic fullerene dendrimers. Chem. Eur. J. 2003, 9, 3867-3875.

19. Carano, M.; Ceroni, P.; Paolucci, F.; Roffia, S.; Da Ros, T.; Prato, M.; Sluch, M.I.; Pearson, C.; Petty, M.C.; Bryce, M.R. Novel fulleropyrrolidinium-based materials. J. Mater. Chem. 2000, 10, 269-273.

Sample Availability: Samples of the compounds $\mathbf{1}$ and $\mathbf{2}$ may be available from the authors.

(C) 2012 by the authors; licensee MDPI, Basel, Switzerland. This article is an open access article distributed under the terms and conditions of the Creative Commons Attribution license (http://creativecommons.org/licenses/by/3.0/). 